\title{
Neolithic settlement dynamics derived from archaeological data and colluvial deposits between the Baar region and the adjacent low mountain ranges, southwest Germany
}

\author{
Jan Johannes Miera ${ }^{1,2, *}$, Jessica Henkner ${ }^{2,3}$, Karsten Schmidt ${ }^{2,3,4}$, Markus Fuchs ${ }^{5}$, Thomas Scholten ${ }^{2,3}$, \\ Peter Kühn ${ }^{2,3}$, and Thomas Knopf ${ }^{2,6}$ \\ ${ }^{1}$ Historisches Seminar, Professur für Ur- und Frühgeschichte, Universität Leipzig, Ritterstrasse 14, 04109 Leipzig, Germany \\ ${ }^{2}$ Sonderforschungsbereich 1070 RessourcenKulturen, Universität Tübingen, Gartenstrasse 29, 72074 Tübingen, Germany \\ ${ }^{3}$ Research Area Geography, Soil Science and Geomorphology Working Group, Eberhard Karls Universität Tübingen, \\ Rümelinstrasse 19-23, 72070 Tübingen, Germany \\ ${ }^{4}$ eScience-Center, Eberhard Karls Universität Tübingen, Wilhelmstrasse 32, 72074 Tübingen, Germany \\ ${ }^{5}$ Department of Geography, Justus Liebig University Giessen, Senckenberstrasse 1, 35390 Giessen, Germany \\ ${ }^{6}$ Institute for Prehistory, Early History and Medieval Archaeology, Department of Early History, \\ Eberhard Karls Universität Tübingen, Schloss Hohentübingen, 72070 Tübingen, Germany \\ * previously published under the name Jan Johannes Ahlrichs
}

Correspondence: Jan Johannes Miera (jan@miera.de)

Relevant dates: $\quad$ Received: 14 January 2019 - Accepted: 21 May 2019 - Published: 27 June 2019

How to cite: $\quad$ Miera, J. J., Henkner, J., Schmidt, K., Fuchs, M., Scholten, T., Kühn, P., and Knopf, T.: Neolithic settlement dynamics derived from archaeological data and colluvial deposits between the Baar region and the adjacent low mountain ranges, southwest Germany, E\&G Quaternary Sci. J., 68, 75-93, https://doi.org/10.5194/egqsj-68-75-2019, 2019.

Abstract:

The present study combines archaeological data with archaeopedological data from colluvial deposits to infer Neolithic settlement dynamics between the Baar region, the Black Forest and the Swabian Jura. A review of the state of archaeological research and an analysis of the processes leading to the discovery of the Neolithic sites and thereby the formation of the current archaeological site distribution in these landscapes is presented. The intensity of land use in the study area is compared with other landscapes in southern Germany using site frequencies. Phases of colluvial deposition are dated using AMS ${ }^{14} \mathrm{C}$ ages of charcoals and luminescence ages of sediments and interpreted as local proxies for a human presence. Archaeological source criticism indicates that the distribution of the Neolithic sites is probably distorted by factors such as superimposition due to erosion and weathering effects limiting the preservation conditions for Neolithic pottery. A reconstruction of Neolithic settlement dynamics is achieved by complementing the archaeological data with phases of colluviation. Evidence for a continuous land use in the Baar region throughout the Neolithic is provided and sporadic phases of land use on the Swabian Jura and in the Black Forest are identified. In the late and final Neolithic, an intensification of colluvial formation can be noticed in the low mountain ranges.

Kurzfassung: In der vorliegenden Studie werden archäologische Daten mit bodenkundlichen Daten aus kolluvialen Ablagerungen verknüpft, um Phasen der Landnutzung während des Neolithikums zu ermitteln und somit neolithische Siedlungsdynamiken zwischen der Baar, dem Schwarzwald und der 
Schwäbischen Alb beschreiben zu können. Ausgehend von einer Auswertung der lokalen archäologischen Forschungsgeschichte und einer quellenkritischen Betrachtung des Fundstoffes erfolgt eine Evaluierung der Verbreitung der gegenwärtig bekannten neolithischen Fundstellen. Auf der Basis von Fundstellenfrequenzen wird eine überregionale Einordnung der Intensität der lokalen Siedlungsaktivität vorgenommen. Phasen der Kolluvienbildung werden durch Radiokohlenstoffdatierungen von Holzkohlen und Lumineszenzalter von Sedimenten datiert und als Hinweise auf eine Anwesenheit des Menschen interpretiert. Die quellenkritische Auswertung des Fundstoffes legt den Verdacht nahe, dass die Verbreitung der neolithischen Fundstellen im Arbeitsgebiet durch verschiedene Faktoren beeinflusst wird. Demnach wird die Zugänglichkeit neolithischer Fundstellen durch Über- und Umlagerung aufgrund von Erosion verzerrt und die Erhaltung von Keramik durch lokale Witterungsbedingungen eingeschränkt. Die Beschreibung neolithischer Siedlungsdynamiken gelingt letztlich durch die Korrelation der archäologischen und bodenkundlichen Daten. Für den gesamten Verlauf des Neolithikums lässt sich auf diese Weise eine neolithische Besiedlung der Baar aufzeigen. Im Schwarzwald und auf der Schwäbischen Alb lassen sich hingegen nur sporadische Landnutzungsphasen aufzeigen. Im Spät- und Endneolithikum lässt sich in den Mittelgebirgen eine Verstärkung der Kolluvienbildung beobachten.

\section{Introduction}

The transition from a mobile subsistence based on hunting and gathering to sedentary farming communities marks a turning point in human history. As this shift had far-reaching consequences for the further development of societies, it is often referred to as the "Neolithic Revolution" (Childe, 1936; Teuber et al., 2017). This transition changed not only the human perception of landscapes, but it also had a major impact on the environment (Gerlach, 2003, 2006). The vegetation was affected by local deforestation carried out in order to establish settlements and introduce fields for plant cultivation and for livestock. As soils became an important resource for survival, they needed maintenance with manure and had to be worked with ploughs to ensure sufficient yields (Lüning, 2000). Already in the Early Neolithic, both changes in vegetation and ploughing resulted in the erosion of soils in the vicinity of the settlements (Saile, 1993; Semmel, 1995). The correlate sediments of soil erosion caused by human activities are called colluvial deposits and can be seen as pedosedimentary archives of human activities in the landscape (Leopold and Völkel, 2007; Kadereit et al., 2010; Kühn et al., 2017). Because they are proxies for land use, they can be used to study pre- and early historic human-environment interactions (Dotterweich, 2008; Fuchs et al., 2011; Pietsch and Kühn, 2017; Voigt, 2014). Colluvial deposits always represent the adjacent upward slope areas and therefore provide local "site biographies" with a high resolution (Henkner et al., 2017, 2018a, c).

So far, colluvial deposits have been used mainly to investigate the long-term consequences of pre- and early historic agriculture in the lowlands in southwestern Germany. Prehistoric land use in low mountain ranges has rarely been investigated using archaeopedological methods (Fuchs et al., 2011; Ahlrichs, 2017; Henkner et al., 2018a, c). Especially in these landscapes, pedological datasets from colluvial deposits are an important supplement to archaeological data. Low mountain ranges such as the Black Forest in southwestern Germany are often densely forested and cannot be adequately investigated solely by using archaeological methods. As a consequence, the kind and intensity of prehistoric land use in this landscape has been a matter of speculation for decades (Lais, 1937; Valde-Nowak, 2002). Due to the climate, relief and soils, the agricultural potential of the Black Forest is fairly limited in comparison to adjacent lowlands, where fertile soils on loess are abundant (Gradmann, 1931, 1948). Therefore, it has been suspected for a long time that this unfavourable landscape was basically avoided in prehistoric times and not colonized before the High Middle Ages (e.g. Schreg, 2014; Ahlrichs, 2017).

However, research from recent decades has provided increasing evidence for early phases of land use dating back to the Neolithic (Frenzel, 1997; Valde-Nowak, 1999; Rösch, 2009). Consequently, the archaeological and archaeobotanical research from the last three decades opens the demand for a reassessment of the relationship between favourable and unfavourable landscapes in the Neolithic. Currently, an interdisciplinary research project at the University of Tübingen takes up this issue using methods from prehistoric archaeology and soil science. The research presented in this paper focuses on the following objectives:

- evaluation of the archaeological data and an identification of factors that influenced the current distribution of the Neolithic sites

- discussion of Neolithic settlement dynamics between the Baar region, the Black Forest and the Swabian Jura with a high spatial and chronological resolution by synchronizing archaeological and pedological data. 


\section{Regional setting}

The study area is located northwest of Lake Constance in the federal state of Baden-Württemberg, southwestern Germany. Geographically, it includes three landscapes: the southeastern part of the central Black Forest, the Baar region and the southwestern part of the Swabian Jura (Fig. 1). The topography changes significantly between these landscapes (Gradmann, 1931; Reichelt, 1977; Schröder, 2001). Deeply cut valleys with steep slopes characterize the Black Forest with an elevation of up to $1100 \mathrm{~m}$ a.s.l., while the southwestern part of the Swabian Jura consists of several high plateaus such as the Heuberg and Lindenberg with elevations up to $1000 \mathrm{~m}$ a.s.l., separated by wide river valleys. The Baar region, however, is an elevated basin-shaped landscape (German: Hochmulde) with an average elevation of 600$800 \mathrm{~m}$ a.s.l. and gentle rolling slopes. In contrast to the Baar region, the two low mountain ranges represent agriculturally unfavourable regions with an oceanic climate (Reichelt, 1977; Tanha, 1986). This is due to high amounts of annual precipitation between 1000 and $1900 \mathrm{~mm}$, low average temperatures ranging from 4 to $6^{\circ} \mathrm{C}$ as well as long periods of winter and frost (Gradmann, 1931; Knoch, 1953). The climate in the Baar region is more continental with an average annual temperature of $7-8^{\circ} \mathrm{C}$ and an average precipitation of $850 \mathrm{~mm}$ per year (Siegmund, 1999, 2006). In addition, the landscapes can be differentiated with regard to their pedology (Kösel and Rilling, 2002; Lazar, 2005; Lazar and Rilling, 2006). Due to fertile soils on loess, the local population used to describe the Baar region as the breadbasket of Baden (Reich, 1859; Deecke, 1921). This is in contrast to the Black Forest, where low-yielding and acidic soils limit the agricultural potential. The Swabian Jura is characterized by a karst landscape with low-yielding soils as well.

\section{Methods}

\subsection{Assessment of archaeological site distributions}

In order to study the pre- and early historic settlement dynamics in this regional setting, an archaeological database was set up in 2014. In total, we recorded 1826 archaeological sites using local area files (German: Ortsakten) from the State Office for Cultural Heritage Baden-Württemberg. The sites date from the late Upper Palaeolithic to the end of the 12th century CE (Ahlrichs et al., 2016; Ahlrichs, 2017). The database includes 107 sites that can be used for a discussion of Neolithic land use and settlement dynamics. In large study areas like this, changes in settlement patterns can be described and investigated by comparing distribution maps with different time frames (Schier, 1990; Saile, 1998; Pankau, 2007). However, as suggested by Sommer (1991), Gerhard (2006) and Eggert (2012), it is necessary to examine the archaeological data in detail in order to evaluate dis- tribution patterns and thus to provide a reliable analysis of settlement dynamics.

\subsubsection{State of local research}

First of all, it is necessary to discuss the genesis of the archaeological record. This includes a literature review with respect to the local history of archaeological research. Within this framework, the general nature of the available data will be presented with focus on geographical as well as chronological aspects. To visualize changes in settlement patterns in a geographic information system (GIS), we digitized the position (EPSG: 31467 ) of each recorded site if it could be located within a radius of $\pm 250 \mathrm{~m}$ based on recent map information. The detection of settlement dynamics requires an accurate dating for the sites of interest with a chronological resolution as high as possible. Therefore, for each recorded site, the available literature was screened for information regarding its chronological position. We distinguished four degrees of chronological precision: epoch, period, phase and sub-phase (Eggert, 2012; Eggert and Samida, 2013).

\subsubsection{Intentionality of site discoveries}

In addition, quantitative analyses of the circumstances leading to the discovery of the recorded Neolithic sites are necessary. It is crucial to distinguish intentional discoveries from accidental ones (Wilbertz, 1982; Schier, 1990; Pankau, 2007). Intentional discoveries can be the result of field surveys, aerial photography, analysis of airborne light detection and ranging (lidar) data, research excavations, rescue excavations and small prospections. On the other hand, archaeological sites can be discovered accidentally in the course of construction measures, agricultural and forestry activities, land consolidation (German: Flurbereinigung), the extraction of raw materials, or randomly when people go for a walk or go hiking. Finally, historical records mentioning prehistoric sites are also included in this category as well as sites that were already known for a long time by local residents before archaeologists discovered their significance - this applies especially to easily accessible structures such as (burial) mounds, ditches or remnants of walls. For a better assessment of the data for the Neolithic, the interpretation of the analyses will also consider the data for the Bronze Age and the pre-Roman Iron Age.

\subsubsection{Depth of sites}

In addition, the depth of a site in relation to the modern surface can be inferred from the circumstances of its discovery (Schier, 1990; Saile, 1998). They can be grouped in a way which allows a differentiation between sites discovered below, close to or on the modern surface (see Table 2). This analysis takes the data for the Bronze Age and the pre-Roman Iron Age into account as well. 


\subsubsection{Site distribution in relation to modern land use}

Furthermore, modern land use strategies have an impact on the conservation and visibility of prehistoric sites (Schiffer, 1987; Sommer, 1991). Therefore, an analysis of site distributions against the background of different land use types is recommended (Pankau, 2007; Ahlrichs, 2017). For a study of this kind, we use CORINE Land Cover data, provided by the European Environment Agency (EEA) (European Environment Agency, 2007). This raster dataset with a resolution of $100 \mathrm{~m}$ contains 44 types of modern land use classes. However, for archaeological purposes, it is appropriate to aggregate these classes to seven main types: urban areas, forests, arable land, grassland, water bodies, bogs or swamps, and landfills or dumpsites (Ahlrichs, 2017). In order to assess whether certain types of land use may lead to distortions in the distribution of prehistoric sites, we use the $\chi^{2}$ test (Shennan, 1988).

\subsubsection{Weathering effects on pottery, stone and coins}

The local topography has an influence on the preservation and accessibility of archaeological sites. At certain relief positions, such as upper slopes or crests, artefacts are exposed to weathering for longer time periods and thus have worse conservation conditions than artefacts on foot slopes or in valleys, where they are covered (and thus protected) by sediment due to erosion (Pasda, 1994, 1998; Saile, 2002). Another important factor is the material the artefacts are made of, i.e. pottery, is less resistant to weathering than stone or metal (Geilmann and Spang, 1958; Schiffer, 1987). Therefore, we defined three groups: pottery, stone artefacts and coins. We used artefacts from settlement contexts and single finds dating to "prehistory", the Palaeo-, Meso- and Neolithic, the Bronze Age, the pre-Roman Iron Age and the Roman Empire (Table 4). We deliberately excluded artefacts from graves because they are directly buried after deposition and less exposed to weathering. In order to establish whether the local topography does indeed influence the preservation of prehistoric artefacts, we analysed the distribution of the three material groups using a non-dimensional unit called morphometric protection index (MPI) from Yokoyama et al. (2002) in the System for Automated Geoscientific Analyses (SAGA) geographic information system (GIS) (Conrad et al., 2015). This analysis is based on a revised and errorcorrected version of a digital elevation model (DEM) with a resolution of $90 \mathrm{~m}$ derived from the Shuttle Radar Topography Mission (SRTM) carried out by the National Aeronautics and Space Administration (NASA) (Jarvis et al., 2008). However, due to the chronological composition of the three material groups, this analysis provides only general information regarding the effect of weathering due to topographic openness. Because of the small number of Neolithic sites in this study area, it is not possible to perform such an analysis only for the Neolithic.

\subsubsection{Local site frequencies in relation to other study areas}

The local site frequency (German: Fundstellenfrequenz) is determined and compared with other regions in southern Germany (Fig. 6) in order to evaluate local changes in demography and settlement intensity. This statistical value indicates how many sites came into existence in the course of a century and thus represents an indicator of the intensity of settlement. The site frequency is calculated by multiplying the number of archaeological sites of a period by 100 and then dividing it by the duration of the period in years (Saile, 1998; Schefzik, 2001; Pankau, 2007).

\subsection{Investigation of colluvial deposits}

\subsubsection{Field methods}

The archaeological database was used to select 13 locations for the investigation of colluvial deposits in the study area (Fig. 1). In the Black Forest, colluvial deposits were investigated at the spring sources of the Breg and the Brigach rivers as well as at Bubenbach and Lehmgrubenhof. In the Baar region, colluvial deposits were studied at Magdalenenberg, Grüningen, Fürstenberg, Geisingen and Spaichingen. Phases of colluvial deposition were studied on the Lindenberg and the Heuberg (Böttingen, Königsheim and Rußberg). Humans can force phases of colluviation through a variety of activities affecting the vegetation, such as grazing and farming, deforestation, mining, building settlements, ramparts or other infrastructures (Starkel, 1987; Leopold and Völkel, 2007). However, it is difficult to conclude directly from a colluvial deposit the activities leading to its formation. In general, colluvial deposits lacking archaeological finds are more likely to be the result of agricultural activities or deforestation than of settlement activities. Colluvial deposits containing scattered archaeological finds qualify as relocated material from a settlement located in the catchment area of the colluvial deposit (Wunderlich, 2000; Niller, 1998). It is possible to correlate phases of colluviation with archaeological data because the deposits can be dated as well (Ahlrichs et al., 2016; Ahlrichs, 2017; Henkner et al., 2017, 2018a, c).

In total, 68 soil profiles were described between 2013 and 2015 in the field (Henkner et al., 2018a) according to the German soil classification system (Ad-hoc-AG Boden, 2005), the Food and Agriculture Organization of the United Nations (FAO, 2006) as well as the world reference base for soil resources (IUSS Working Group WRB, 2015). A main characteristic for anthropogenic colluvial deposits is a lack of autochthonous pedogenic properties; hence their horizons are designated $\mathrm{M}(\mathrm{M}=$ Latin Migrare, to migrate $)$ in the German soil classification system. In our studies, we use the M horizon together with the FAO nomenclature in order to distinguish between colluvial horizons and others with different pedogenic development (Henkner et al., 2017, 2018a, c). To understand the local stratigraphy of colluvial deposits at each 


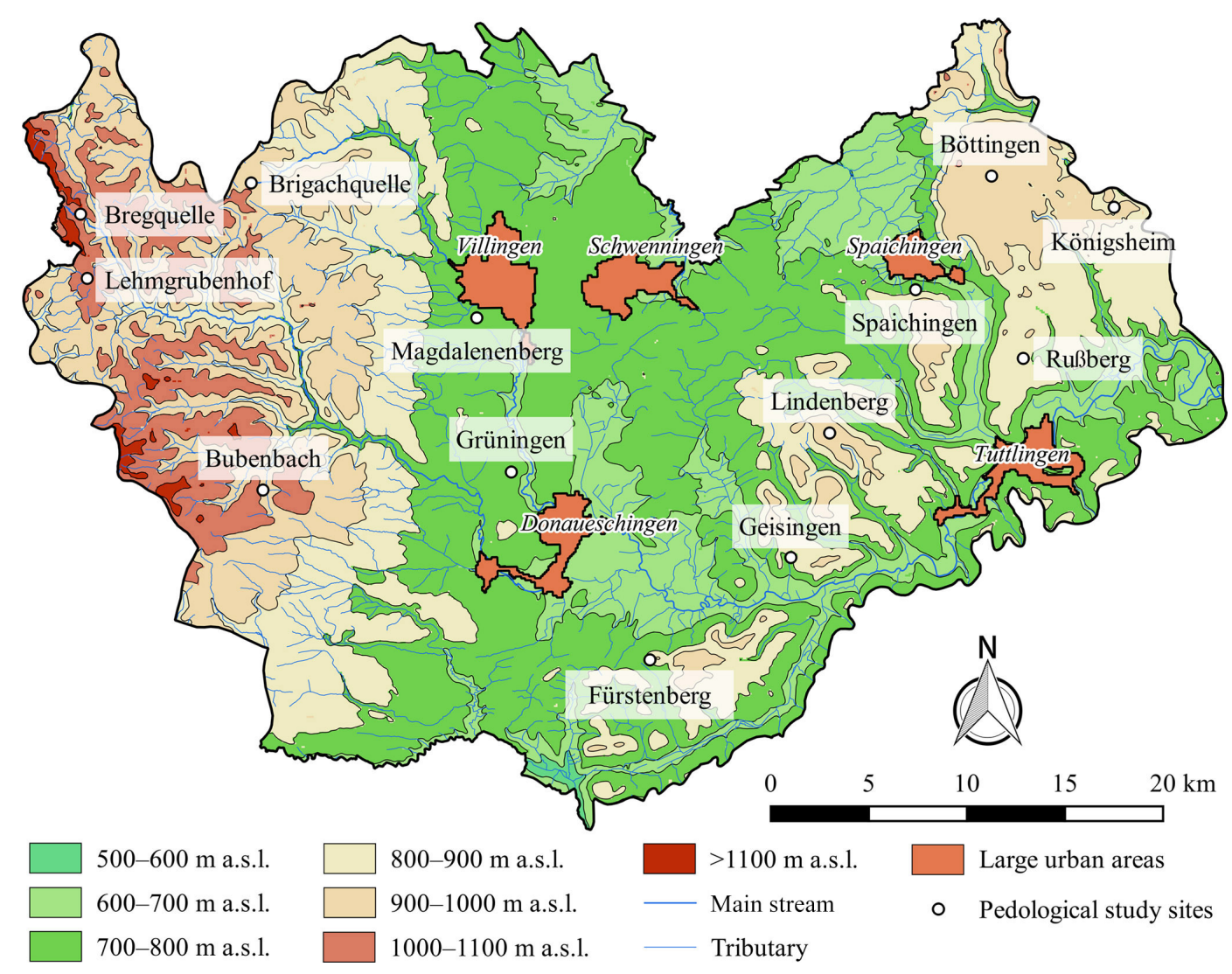

Figure 1. Study area and sites of investigated colluvial deposits. The topography is based on a digital elevation model provided by NASA (Jarvis et al., 2008). The mapping of rivers is based on Amtliches Digitales Wasserwirtschaftliches Gewässernetz (AWGN) provided by Landesanstalt für Umwelt, Messungen und Naturschutz Baden-Württemberg (LUBW).

site, we used catenas, i.e. a sequence of soil profiles extending from the upper slope to foot slope positions, thus covering differences in topography, elevation and drainage as well as erosion or deposition. Samples for dating phases of colluvial deposition were taken from profiles regarded as the most characteristic for a site due to their detailed pedostratigraphy (Henkner et al., 2017, 2018a, c).

\subsubsection{Laboratory methods}

All soil chemical analyses were done in the Laboratory of Soil Science and Geoecology at the University of Tübingen. Total $\mathrm{C}$ and $\mathrm{N}$ contents (mass \%) were analysed using oxidative heat combustion at $1150^{\circ} \mathrm{C}$ in a He atmosphere (element analyser "vario EL III", Elementar Analysensysteme GmbH, Germany, in CNS mode). Soil organic C content (SOC) was determined using $\mathrm{SOC}=\mathrm{C}_{\text {total }}-\mathrm{CaCO}_{3} \times 0.1200428$, and soil organic matter $(\mathrm{SOM})$ was calculated using the factor 1.72 (Ad-hoc-AG Boden, 2005; Eberhardt et al., 2013; Henkner et al., 2018c).

To estimate the deposition ages of colluviation, we used two methods: charcoal samples were taken for radiocarbon dating by means of accelerator mass spectrometry (AMS).
The samples were processed in the ${ }^{14} \mathrm{C}$ laboratories in Jena, Mannheim, Erlangen and Poznań. When interpreting AMS ${ }^{14} \mathrm{C}$ from colluvial deposits, it has to be taken into account that the ages represent the point in time at which the carbon exchange between the wood and the biosphere broke off, i.e. the year in which the sampled tree ring was formed (Taylor and Bar-Yosef, 2014). This age does not necessarily coincide with the time when the charcoal was formed. Subsequently, the $\mathrm{AMS}{ }^{14} \mathrm{C}$ dates usually represent the maximum age of the colluvial deposition from which they were taken (Ahlrichs et al., 2016; Henkner et al., 2017). The calibration of the data was done with OxCal 4.2 and the calibration curve IntCal13 (Bronk Ramsey, 2009; Reimer et al., 2013).

Furthermore, optical stimulated luminescence (OSL) dating was applied, using opaque steel cylinders with a diameter of $4.5 \mathrm{~cm}$ for sampling. For equivalent dose (De) determinations, the coarse-grain $(90-200 \mu \mathrm{m})$ quartz fraction was prepared and measured with a single-aliquot regenerative-dose (SAR) protocol after Murray and Wintle (2000). All luminescence measurements were carried out at the luminescence laboratory of the Justus Liebig University in Giessen, using a Freiberg Instruments Lexsyg reader (Lomax et al., 2014). For data analysis, the $\mathrm{R}$ luminescence package (Kreutzer et al., 


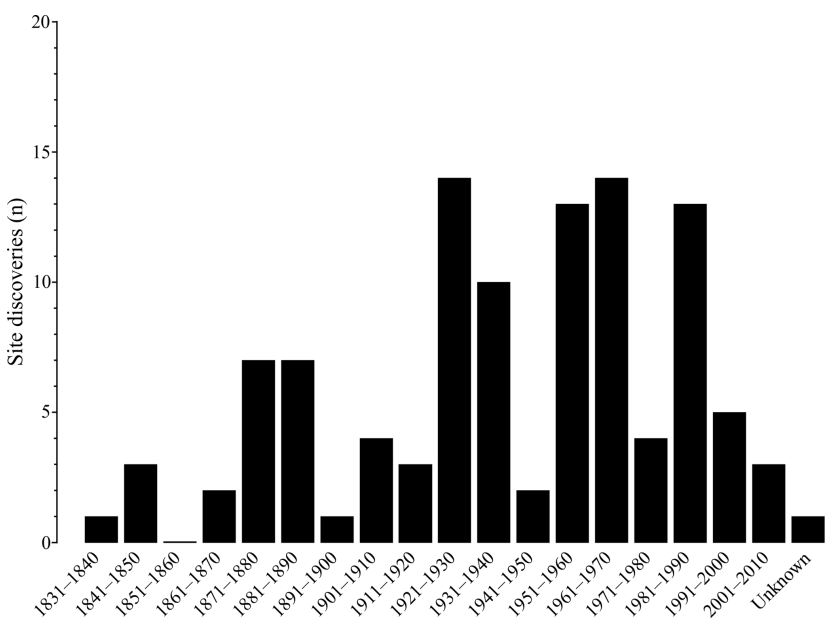

Figure 2. Distribution of Neolithic site discoveries.

2016) was used. In contrast to radiocarbon dating, OSL is assumed to date the time of colluvial deposition because it determines the period of time when the sampled sediment was last exposed to sunlight. Postsedimentary reworking (e.g. by bioturbation), however, should generally not be neglected when luminescence ages are interpreted as ages of colluvial deposition (see Reimann et al., 2017). A prerequisite for the successful application of this method is that the sampled sediments were sufficiently exposed to sunlight during their relocation. In case of insufficient daylight exposure, OSL dating would result in an age overestimation (Bußmann, 2014; Henkner et al., 2018a). Nevertheless, colluvial deposits can generally be dated successfully by OSL as demonstrated in numerous studies from various landscapes and cultural periods (Fuchs and Lang, 2009; Kadereit et al., 2010).

\section{Results}

\subsection{Archaeological data}

\subsubsection{State of local research}

Since the mid-thirties of the 19th century, Neolithic sites have been known in the study area (Fig. 2). Several decades later, Wagner (1908), Haug and Sixt (1914) published the first comprehensive archaeological catalogues which included these early discovered sites. From the 1920s onwards until the 1950s, Paul Revellio led the archaeological research in the Baar region (Hall, 1968). He carried out rescue excavations at construction sites as well as field surveys and small prospections. Revellio recorded and published most of the Neolithic sites discovered during these three decades (Revellio, 1924, 1932 and 1938). In the 1930s, Fischer (1936) and Stoll (1941 and 1942) also studied the Neolithic settlement dynamics in the region. When Revellio retired in the 1950s, Rudolf Ströbel continued his work (Benzing, 1974). After his death, Spindler (1977) and Schmid (1991 and 1992) were the only researchers who provided analyses of the $\mathrm{Ne}$ olithic sites discovered since the 1960s. In addition, few Neolithic sites were discussed in studies with a supra-regional focus (Paret, 1961; Itten, 1970; Pape, 1978). In general, it has to be noted that very few Neolithic sites in the study area have been investigated in the field (for exceptions see Wagner, 2014; Seidel, 2015). The vast majority were merely registered and published in the form of short site reports (see Schmid, 1992; Ahlrichs, 2017). In this context, it is noteworthy that in the course of the 20th century, several researchers carried out field surveys in the Baar region and adjacent landscapes. Although the surveyed territories cover a large part of the study area (Fig. 3), only one Neolithic site was actually discovered in the course of these surveys (Ahlrichs, 2017).

Against the background of this research history, we recorded 107 archaeological sites dating to the Neolithic. Based on the available data in the local area files and the literature we were able to assign a point coordinate to 75 sites (Fig. 7). In the remaining 32 cases this was not possible due to a lack of geographical information. Furthermore, after a review of the sites with regard to their archaeological dating, we were able to assign 49 sites to different Neolithic periods. Due to the nature of the artefacts, it was not possible to date the Neolithic sites on the level of phases or even sub-phases. The remaining 58 sites date to the "Neolithic" in general because the artefacts recovered at these sites are too fragmented or atypical for any further chronological specification. Therefore, more than half of the recorded sites are not suitable for the description of local-settlement dynamics. These results mirror the state of archaeological research of the individual sites: out of 107 registered Neolithic sites, no more than 12 sites were studied in the course of research excavations. Out of those 12 sites, 9 had to be excavated because they were discovered during excavations of archaeological sites dating to later periods. Furthermore, rescue excavations took place at four Neolithic sites after their initial discovery. This unbalanced ratio between excavated and not excavated sites has been observed in other study areas too (Schmotz, 1989). With respect to the state of research in the Baar region and adjacent landscapes, 20 sites qualify as settlements due to the presence of grinding stones and/or features such as pits or postholes. At five sites, human remains were recovered, classifying these locations as burial sites. The remaining 82 sites are composed of single finds or small artefact assemblages that currently do not allow a more detailed description of the activities that took place at these sites (Ahlrichs, 2017).

\subsubsection{Intentionality of site discoveries}

In contrast to the Bronze Age and the pre-Roman Iron Age, an extraordinarily large number of Neolithic sites were discovered accidentally (Table 1). In total, 87 out of 107 sites are associated with non-intentional modes of discovery. Most of them were found randomly $(n=38)$ during agricultural and forestry activities $(n=18)$ or in the course of construc- 


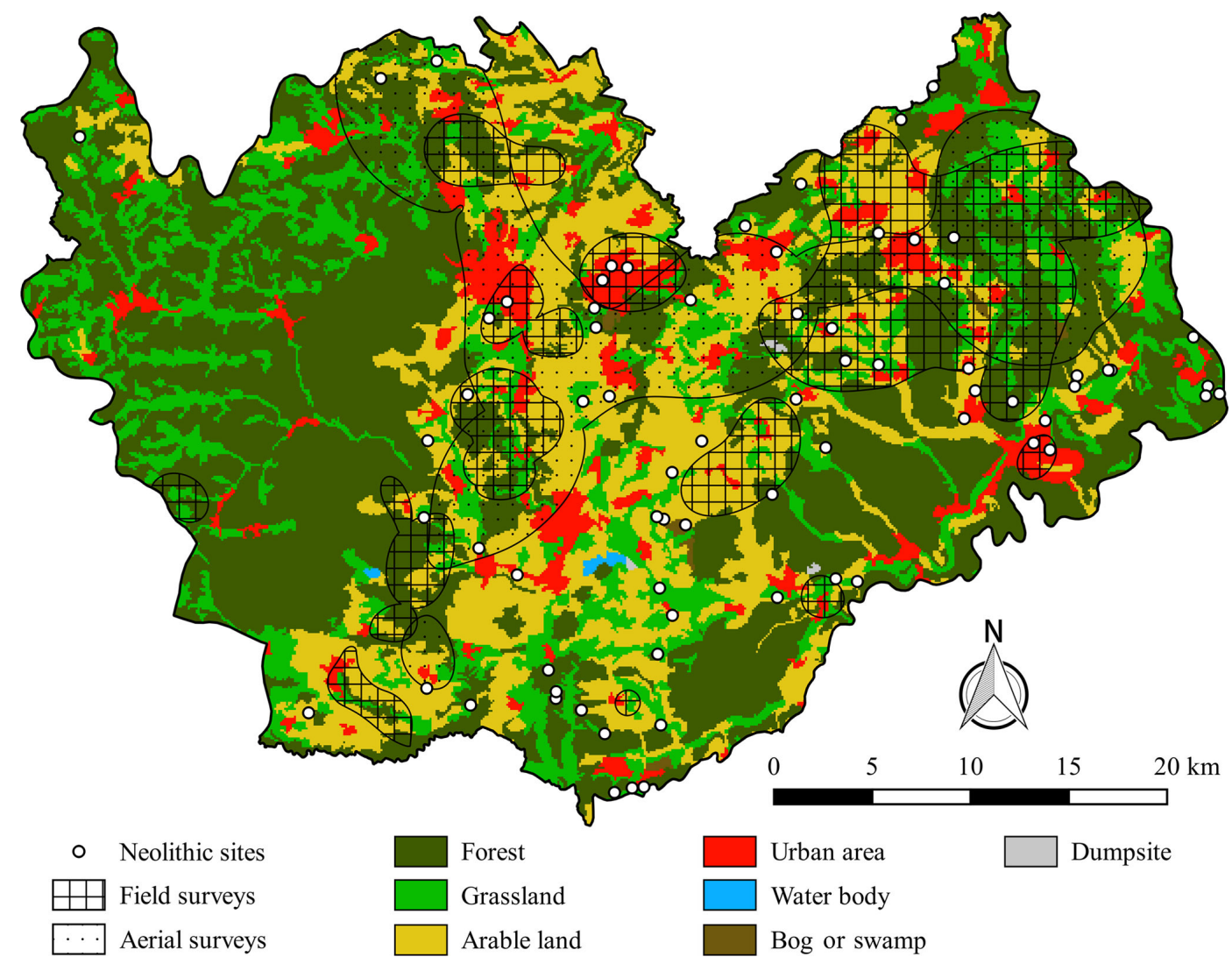

Figure 3. Modern land use according to CORINE Land Cover data (European Environment Agency, 2007) and areas studied by field surveys (Ahlrichs, 2017).

Table 1. Intentionality of archaeological site discoveries.

\begin{tabular}{llrr|r|r|rr}
\hline Intentionality & Modes of discovery & \multicolumn{2}{c}{ Neolithic } & Bronze Age & Pre-Roman Iron Age \\
\cline { 2 - 6 } & & $(n)$ & $(\%)$ & $(n)$ & $(\%)$ & $(n)$ & $(\%)$ \\
\hline \multirow{5}{*}{ Non-intentional } & Long known & 1 & 1 & 3 & 2 & 17 & 8.5 \\
& Random discovery & 38 & 35.5 & 22 & 16 & 28 & 14 \\
& Working measure & 16 & 15 & 48 & 34 & 47 & 23.5 \\
& Eand consolidation & 1 & 1 & 1 & 1 & 2 & 1 \\
& Extraction of raw materials & 8 & 7.5 & 6 & 4 & 3 & 1.5 \\
& Historical records & 0 & 0 & 0 & 0 & 0 & 0 \\
& Agricultural and forestry activities & 18 & 17 & 10 & 7 & 8 & 4 \\
\hline \multirow{5}{*}{ Intentional } & Field survey & 1 & 1 & 18 & 13 & 47 & 23.5 \\
& Lidar data & 0 & 0 & 0 & 0 & 0 & 0 \\
& Aerial photography & 0 & 0 & 0 & 0 & 3 & 1.5 \\
& Research excavation & 9 & 8 & 8 & 6 & 7 & 3.5 \\
& Rescue excavation & 0 & 0 & 0 & 0 & 2 & 1 \\
& Prospection & 0 & 0 & 0 & 0 & 1 & 0.5 \\
\hline Unknown & Unknown & 15 & 14 & 24 & 17 & 35 & 17.5 \\
\hline & Sum & 107 & 100 & 140 & $100 \mid$ & 200 & 100 \\
\hline
\end{tabular}


tion measures $(n=16)$. Less than $10 \%$ of the Neolithic sites are associated with intentional modes of discovery. These include the nine Neolithic sites mentioned earlier that were registered during excavations of archaeological sites dating to later periods and a single site that was discovered in a field survey. These results are even more indicative of potential gaps in the distribution of the sites when compared to younger epochs. The numbers of intentionally discovered sites are approximately $19 \%$ for the Bronze Age and 30\% for the pre-Roman Iron Age. Altogether, 18 Bronze Age sites and 47 sites dating to the pre-Roman Iron Age were registered during field surveys (Table 1). This indicates that the material remains from these epochs may be more resistant to weathering compared to the ones dating to the Neolithic. In addition, the numerous discoveries during field surveys can be used to correct potential distortions in the Bronze Age and Iron Age site distributions caused by construction sites in urban areas. However, there is no such balance for the Neolithic sites.

\subsubsection{Depth of sites}

In total, 40 Neolithic sites were discovered on the modern surface, 19 were just slightly below the surface and about another 33 below the surface (Table 2). Initially, these results are quite similar with those for the Bronze Age and the pre-Roman Iron Age. However, a closer look at the archaeological data shows that at just one site Neolithic pottery was found on the recent surface. Overall, at 37 out of 38 sites discovered on the surface the artefacts were made of stone, which is far more resistant to weathering. This is in contrast to the Bronze Age and the pre-Roman Iron Age (Table 2). In total, 43 Bronze Age sites were discovered on the modern surface and at 27 of them pottery was present. In the case of the pre-Roman Iron Age, 92 sites were registered on the modern surface; pottery was found at 60 of them (Ahlrichs, 2017). These results suggest that Neolithic pottery may be less resistant to weathering on the surface than pottery from the Bronze Age and the pre-Roman Iron Age. Consequently, a distortion in the distribution of Neolithic sites is possible, as a preservation of pottery is more likely at topographic positions where it is superimposed shortly after its deposition.

\subsubsection{Site distribution in relation to modern land use}

On arable land, grassland as well as in bogs and at dumpsites about as many Neolithic sites were registered as would be expected with an even distribution over the land use classes (Fig. 3, Table 3). Consequently, these land use classes do not have much influence on the distribution of the sites. In contrast, urban areas and forests seem to have an influence on the distribution of Neolithic sites. In urban areas, the number of registered sites exceed the number of expected sites. This result can be attributed to the fact that construction measures are more likely to occur in settlements than in the other

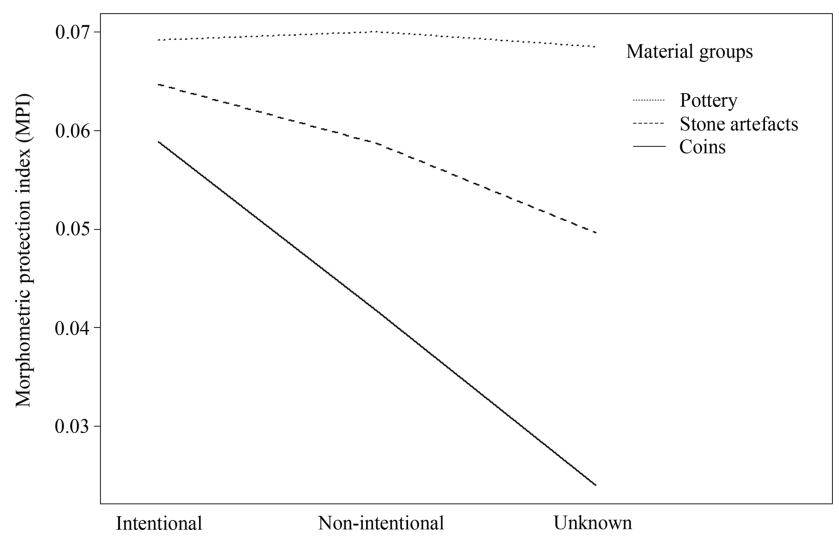

Figure 4. Comparison of average MPI values for pottery, stone artefacts and coins with regard to the intentionality of the site discoveries

land use classes. As the frequency of construction measures increases, so does the probability of discovering new sites. This can lead to artificial clusters of prehistoric sites in urban areas (Schier, 1990; Gerhard, 2006). As Fig. 3 indicates, this does not apply to the Neolithic sites in this study area, since none of the modern settlements correlates with a remarkably large number of Neolithic sites. However, it is noticeable that several sites in the valleys of the Swabian Jura were discovered during construction measures. It has been suggested in earlier research that the density of prehistoric sites in the valleys of the Swabian Jura is low because their archaeological visibility and accessibility are reduced due to erosion (Paret, 1961; Wahle, 1973). This seems to apply to our study area as well. In addition, the visibility of prehistoric sites is limited by dense vegetation in areas covered by forests. As a result, fewer Neolithic sites were registered in forests than expected. This is a crucial factor in understanding the absence of Neolithic sites in Black Forest and in large parts of the Swabian Jura (Lais, 1937; Valde-Nowak, 2002; Pankau, 2007).

\subsubsection{Weathering effects on pottery, stone and coins}

Each of the three material groups shows a specific frequency distribution over the morphometric protection index (MPI). In fact, pottery and coins can be differentiated due to their distinct trends (Table 5). As can be seen in Fig. 5, pre- and early historic pottery has often been registered in topographical positions with a high MPI such as foot slopes or valleys. In contrast, the frequency distribution of coins concentrates in topographic areas with a fairly small MPI, while stone artefacts take an intermediate position between these groups. Compared to pottery, however, there is also a trend towards areas with small MPIs for stone artefacts (Fig. 5). Since these trends might have been influenced by the circumstances leading to the discovery of the sites, an additional analysis was carried out taking into account the intentionality of the site discoveries. Figure 4 shows the average MPI values of the 
Table 2. Relation of archaeological sites to the modern surface.

\begin{tabular}{llrr|rr|rr}
\hline Relation to surface & Modes of discovery & \multicolumn{2}{c}{ Neolithic } & Bronze Age & Pre-Roman Iron Age \\
\cline { 2 - 6 } & & $(n)$ & $(\%)$ & $(n)$ & $(\%)$ & $(n)$ & $(\%)$ \\
\hline \multirow{4}{*}{ Above surface } & Field survey & 1 & 0.93 & 18 & 12.86 & 47 & 23.5 \\
& Random discovery & 38 & 35.51 & 22 & 15.71 & 28 & 14 \\
& Long known & 1 & 0.93 & 3 & 2.14 & 17 & 8.5 \\
& Historical records & 0 & 0 & 0 & 0 & 0 & 0 \\
\hline \multirow{5}{*}{ Close to surface } & Agricultural or forestry activities & 18 & 16.82 & 10 & 7.14 & 8 & 4 \\
& Lidar data & 0 & 0 & 0 & 0 & 0 & 0 \\
& Aerial photo & 0 & 0 & 0 & 0 & 3 & 1.5 \\
& Land consolidation & 1 & 0.93 & 1 & 0.71 & 2 & 1 \\
\hline \multirow{5}{*}{ Below surface } & Working measure & 16 & 14.95 & 48 & 34.3 & 47 & 23.5 \\
& Research excavation & 9 & 8.41 & 8 & 5.71 & 7 & 3.5 \\
& Rescue excavation & 0 & 0 & 0 & 0 & 2 & 1 \\
& Prospection & 0 & 0 & 0 & 0 & 1 & 0.5 \\
& Extraction of raw materials & 8 & 7.5 & 6 & 4.29 & 3 & 1.5 \\
\hline Unknown & Unknown & 15 & 14.02 & 24 & 17.14 & 35 & 17.5 \\
\hline
\end{tabular}

Table 3. Distribution of Neolithic sites over modern land use.

\begin{tabular}{lrrrr}
\hline Land use & $\begin{array}{r}\text { Spatial abundance } \\
(\%)\end{array}$ & $\begin{array}{r}\text { Recorded } \\
\text { sites }(n)\end{array}$ & $\begin{array}{r}\text { Expected } \\
\text { sites }(n)\end{array}$ & $\chi^{2}$ value \\
\hline Water bodies & 0.1 & 0 & 0.08 & 0.08 \\
Urban areas & 7.88 & 16 & 5.91 & 17.23 \\
Arable land & 24.43 & 22 & 18.32 & 0.74 \\
Grassland & 20.16 & 15 & 15.12 & 0 \\
Forest & 47.1 & 22 & 35.33 & 5.03 \\
Bogs or swamps & 0.25 & 0 & 0.19 & 0.19 \\
Dumpsites or landfills & 0.08 & 0 & 0.06 & 0.06 \\
\hline Sum & 100 & 75 & 75 & 23.33 \\
\hline
\end{tabular}

The critical $\chi^{2}$ value for 6 degrees of freedom is at 22.46 (significance level: $0.001 \%$ ).

In this case, the site distribution is highly significantly unequal (see Ihm et al., 1978, p. 595).

intentional and non-intentional site discoveries for each material group. The results demonstrate that pottery was registered in topographic positions with a very specific MPI, regardless of whether they were recorded in the course of intentional or non-intentional modes of discovery. This cannot be seen in the other groups. These results suggest that the topography has an influence on the preservation and accessibility of pre- and early historic pottery and thus constitutes a crucial factor with respect to the understanding of site distributions in the study area.

\subsubsection{Local site frequencies in relation to other study areas}

According to the available archaeological data, the Neolithic settlement of the Baar region and adjacent landscapes are characterized by extremely low site frequencies (Table 6).

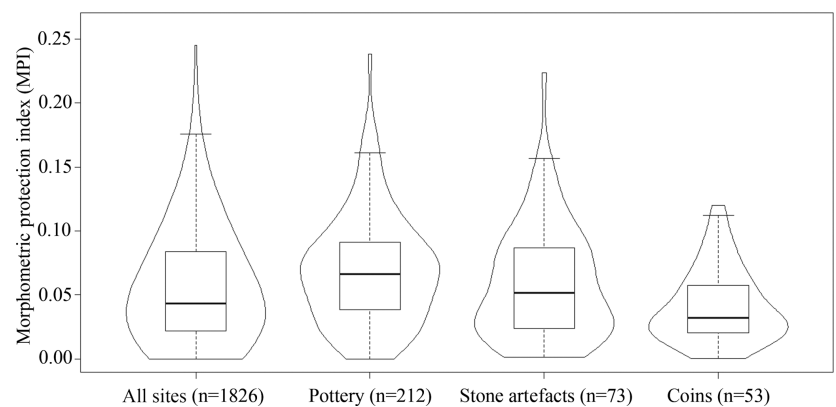

Figure 5. General comparison of average MPI values for pottery, stone artefacts and coins (see also Table 5). 
Table 4. Distribution of material groups over different epochs and types of archaeological sites.

\begin{tabular}{llrrrr}
\hline Epoch & Type of site & Pottery & $\begin{array}{r}\text { Stone } \\
\text { artefacts }\end{array}$ & Coins & Sum \\
& & & 1 & 0 & 19 \\
"Prehistory" & Settlement & 18 & 0 & 0 & 1 \\
& Single finds & 1 & 0 & 0 & 0 \\
& Settlement & 0 & 2 & 0 & 2 \\
\hline \multirow{2}{*}{ Palaeolithic } & Single finds & 0 & 1 & 0 & 1 \\
& Settlement & 0 & 3 & 0 & 3 \\
\hline \multirow{2}{*}{ Nesolithic } & Single finds & 0 & 10 & 0 & 19 \\
& Settlement & 9 & 47 & 0 & 48 \\
\hline \multirow{2}{*}{ Bronze Age } & Single finds & 1 & 2 & 0 & 52 \\
& Settlement & 50 & 2 & 0 & 8 \\
\hline \multirow{2}{*}{ Pre-Roman Iron Age } & Single finds & 6 & 3 & 0 & 97 \\
& Settlement & 94 & 0 & 6 & 11 \\
\hline \multirow{2}{*}{ Roman Empire } & Single finds & 5 & 1 & 12 & 28 \\
& Settlement & 15 & 1 & 35 & 49 \\
\hline Sum & Single finds & 13 & 73 & 53 & 338 \\
\hline
\end{tabular}

Table 5. Comparison of average MPI values for pottery, stone artefacts and coins (see also Fig. 5).

\begin{tabular}{lrrrrrrr}
\hline Material group & Minimum & First quartile & Median & Mean & Second quartile & Maximum & Standard deviation \\
\hline All sites $(n=1826)$ & 0 & 0.0217 & 0.0431 & 0.0557 & 0.0839 & 0.245 & 0.0429 \\
Pottery $(n=212)$ & 0 & 0.0388 & 0.066 & 0.069 & 0.091 & 0.2381 & 0.0436 \\
Stone artefacts $(n=73)$ & 0.0012 & 0.024 & 0.0515 & 0.0588 & 0.0866 & 0.2236 & 0.0435 \\
Coins $(n=53)$ & 0.0003 & 0.0204 & 0.032 & 0.0416 & 0.0573 & 0.1198 & 0.0283 \\
\hline
\end{tabular}

The Early Neolithic and the Final Neolithic are the only periods for which we could calculate site frequencies of one and nearly two sites per hundred years. The other Neolithic periods are characterized by even smaller site frequencies. In fact, similar results cannot be observed in any other study area in southern Germany (Table 6, Fig. 6). On the contrary, in landscapes such as the Wetterau or Maindreieck, frequencies of up to 30 sites per century can be demonstrated. The Brenz-Kocher Valley on the Swabian Jura is the only landscape with similarly low site frequencies. In general, it can be assumed that the calculated site frequencies do reflect regional trends in Neolithic settlement dynamics, even though the results may be affected to a certain degree by local research traditions. Altogether, we assume that the Neolithic settlement density must have been very low in the study area. This probably results from the limited accessibility of $\mathrm{Ne}$ olithic sites as well as poor conditions for the conservation of pottery due to the topography and modern land use.

\subsection{Colluvial deposits}

\subsubsection{Archaeopedological dataset}

The entire dataset includes 93 AMS ${ }^{14} \mathrm{C}$ datings of charcoals, 47 luminescence datings of colluvial deposits and laboratory results of 728 bulk soil samples (Henkner et al., 2018b). Since this paper deals with the Neolithic land use, this section will focus on those $21 \mathrm{AMS}{ }^{14} \mathrm{C}$ ages (Table 7) and 9 luminescence ages (Table 8) associated with the Neolithic. In the following, the results for each of the three landscapes are presented.

\subsubsection{The Baar region}

At the beginning of the Neolithic, phases of land use triggered colluvial formation at Magdalenenberg and Fürstenberg. A luminescence age from Mag1_14 (GI0132) and a radiocarbon age from Fue9 (Erl-20278) date the related colluvial deposits into the Early Neolithic period. This is supplemented by three OSL samples covering the entire time frame from the early to the Younger Neolithic due large standard errors (GI0183, GI0184, GI0248). There are few sam- 
Table 6. Supra-regional comparison of Neolithic site frequencies (see also Fig. 6).

\begin{tabular}{lrrrrrl}
\hline Region & $\begin{array}{r}\text { Early } \\
\text { Neolithic }\end{array}$ & $\begin{array}{r}\text { Middle } \\
\text { Neolithic }\end{array}$ & $\begin{array}{r}\text { Younger } \\
\text { Neolithic }\end{array}$ & $\begin{array}{r}\text { Late } \\
\text { Neolithic }\end{array}$ & $\begin{array}{r}\text { Final } \\
\text { Neolithic }\end{array}$ & Reference \\
\hline Baar & 1.2 & 0.83 & 0.11 & 0.86 & 1.85 & This study \\
Brenz-Kocher Valley & 5 & 1.5 & 2.33 & - & 1.23 & Pankau (2007) \\
Estuary of the Isar river & 5.2 & 13.5 & 3.22 & - & 3.54 & Schmotz (1997, 2001) \\
Northwestern Maindreieck & 11.8 & 2.33 & 4.33 & - & 5.08 & Obst (2012) \\
Groß-Gerau & 11.8 & 20.83 & 5 & - & 10.62 & Gebhard (2007) \\
Danube Valley near Regensburg & 13.4 & 20.5 & 3.89 & - & 6.46 & Schier (1985) \\
Ries & 17.6 & 6 & 5.56 & - & 1.23 & Krippner (1995) \\
Maindreieck & 28 & 30 & 5.67 & 5 & 12.46 & Schier (1990) \\
Wetterau & 29.8 & 15.83 & 7.22 & - & - & Saile (1998) \\
\hline
\end{tabular}

Table 7. Neolithic AMS ${ }^{14} \mathrm{C}$ radiocarbon dates from charcoals in colluvial deposits from Fürstenberg (Fue), Magdalenenberg (Mag), Spaichingen (Spa), Geisingen (Gei), Grüningen (Gru), Lehmgrubenhof (Leh), Brigach spring (Bri), Königsheim (Koe), Lindenberg (Lin) and Böttingen (Boe). The data calibrations were done with OxCal 4.2 and the calibration curve IntCal13 (Bronk Ramsey, 2009; Reimer et al., 2013).

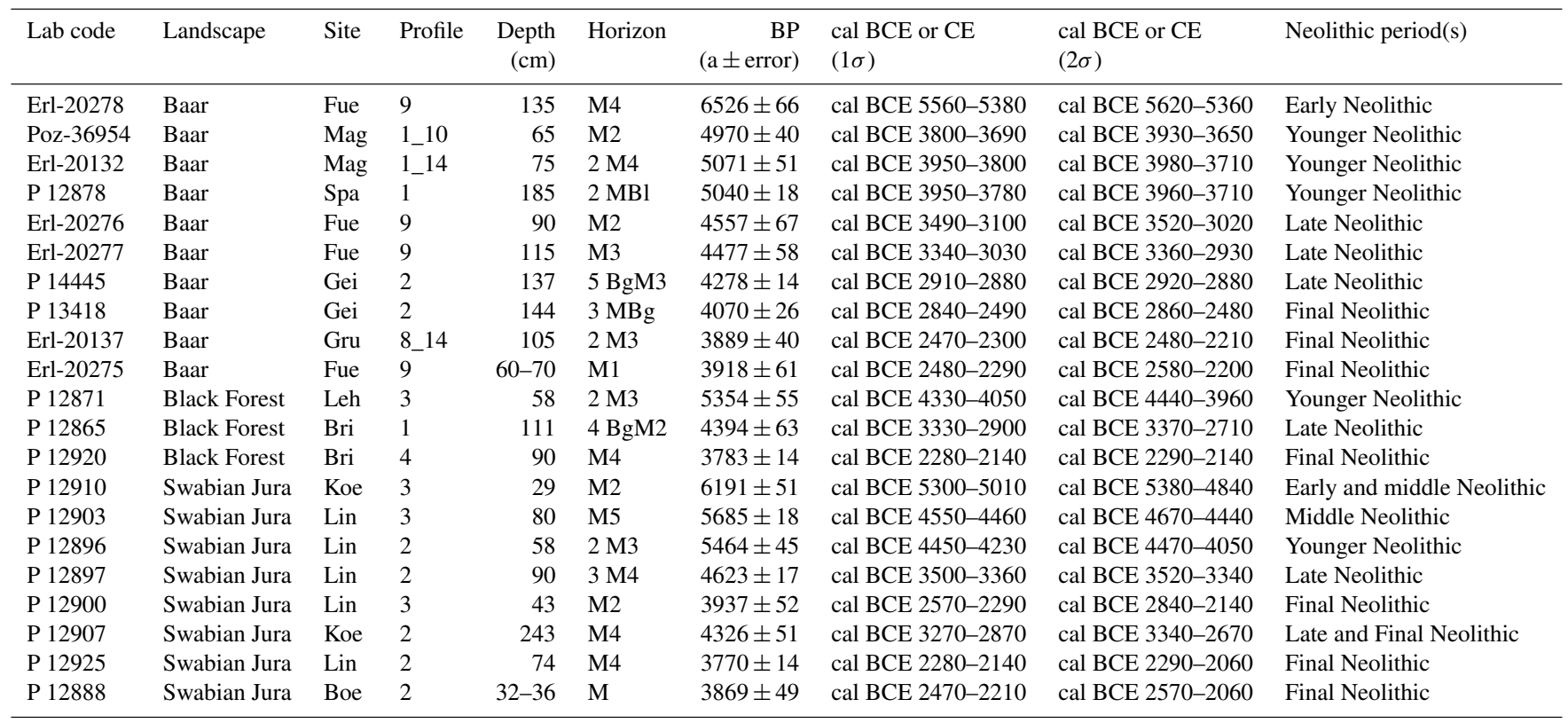

ples dating to the Middle Neolithic. These include the above mentioned OSL samples from Fue8 (GI0183, GI0184) and Fue9 (GI0248) as well as one OSL sample from Mag1_14 (GI0131). The archaeopedological results indicate no significant change in the settlement pattern in the Baar region until the end of the Middle Neolithic. The transition to the Younger Neolithic is marked by a significant increase in radiocarbon ages. In this period, land use continues at Magdalenenberg (Poz-36954, Erl-20132, GI0131) and Fürstenberg (GI0183, GI0184, GI0247, GI0248). Furthermore, an AMS ${ }^{14} \mathrm{C}$ age from Spaichingen ( $\mathrm{P}$ 1278) dates into this period, thus suggesting local settlement dynamics that went along with the human impact on the eastern Baar. For the Late Neolithic, a distinctive human influence can be demon- strated in several soil profiles. While there are no more indications of land use at Spaichingen and Magdalenenberg, a continuation of land use can be seen in soil profiles at Fürstenberg (GI0247, Erl-20276, Erl-20277). An additional phase of colluviation was detected at Geisingen (P 14445) in the southeastern Baar region. These results indicate both an intensification of land use in the southern Baar region but also point to the cultural significance of the Danube Valley for the Late Neolithic farming societies as an important geographical element with respect to traffic and communication. This is also indicated by imported objects such as an axe made of jadeite found at the Fürstenberg and a hatchet made of copper discovered in the Danube Valley (Wagner, 2014; Seidel, 2015; Ahlrichs, 2017). For the Final Neolithic, 


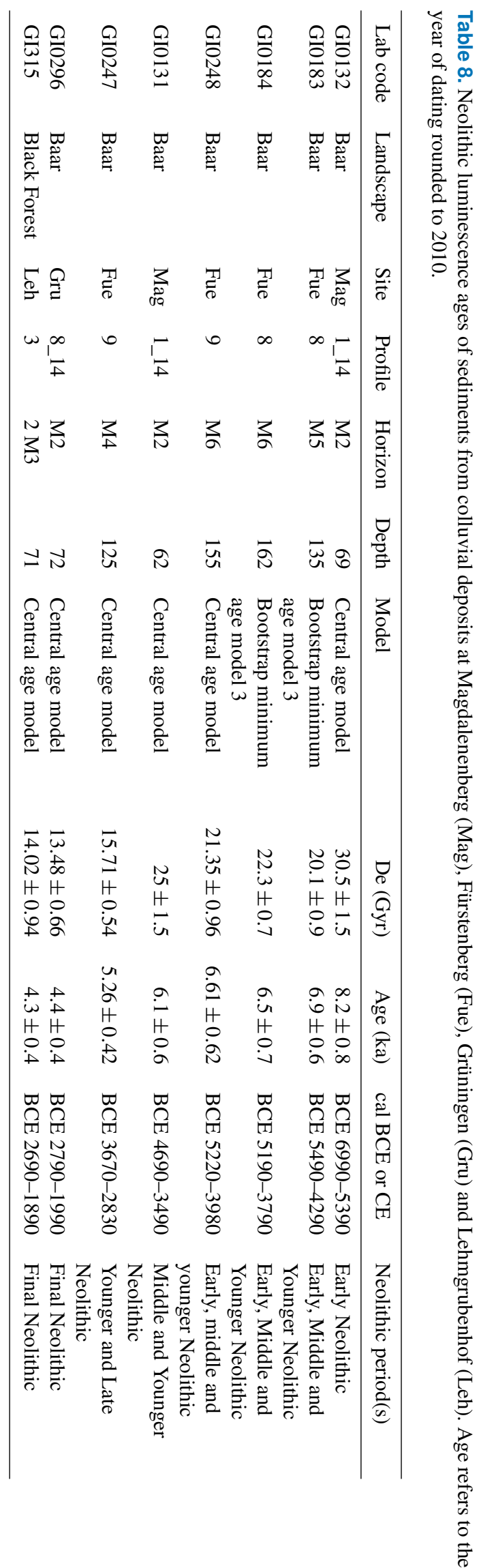

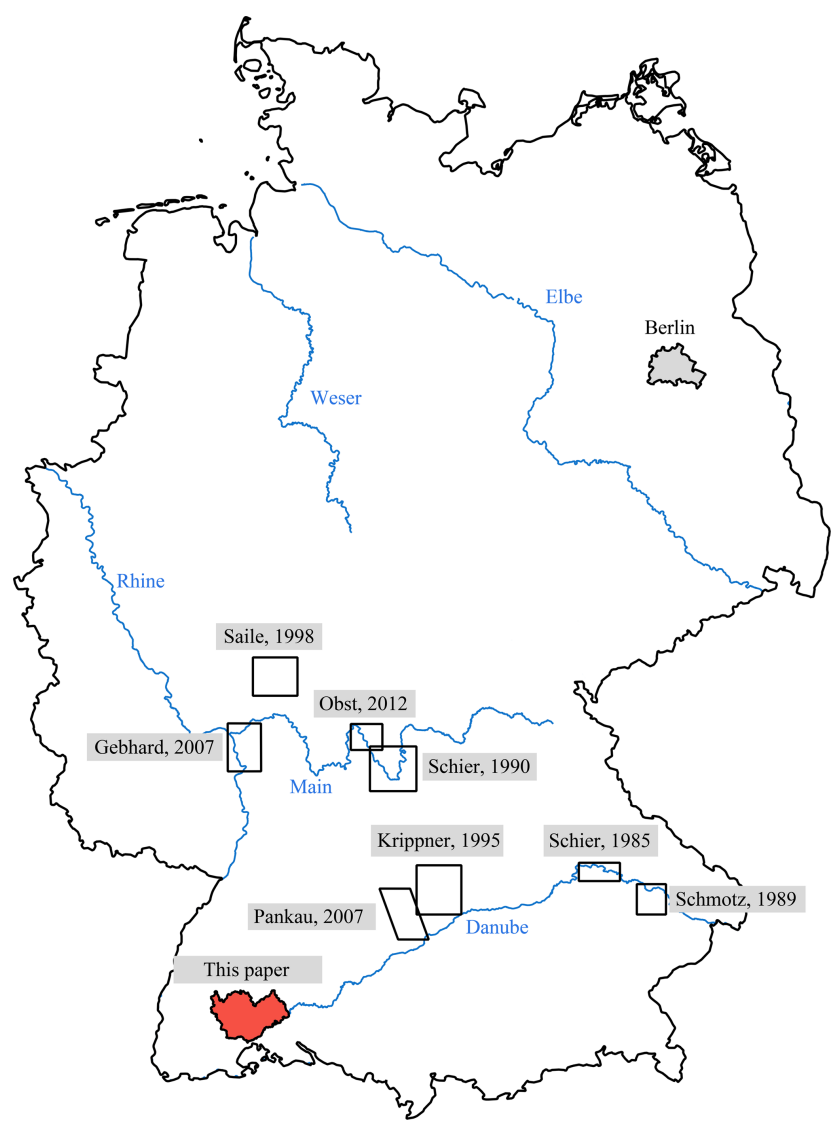

Figure 6. Location of study areas used in discussion on local site frequencies (see Table 6).

the archaeopedological studies indicate settlement dynamics on the western Baar region. At Grüningen, both an AMS ${ }^{14} \mathrm{C}$ age (Erl-20137) and a luminescence age (GI0296) from Gru8_14 point to the formation of a colluvial deposit during the Final Neolithic. Furthermore, AMS ${ }^{14} \mathrm{C}$ dating of charcoals demonstrates a human presence at Fürstenberg (Erl20275) and Geisingen (P 13418).

\subsubsection{The Swabian Jura}

The archaeopedological studies suggest similar developments in the Baar region and on the Swabian Jura, even though the number of AMS ${ }^{14} \mathrm{C}$ and luminescence datings are significantly smaller on the Swabian Jura. A radiocarbon age from Königsheim (P 12910) points to land use on the Heuberg in the Early Neolithic. The Middle Neolithic is represented by two radiocarbon ages from the Swabian Jura. Whereas the AMS ${ }^{14} \mathrm{C}$ dating from Königsheim (P 12910) covers both the early and the Middle Neolithic, and the charcoal sample from Lindenberg (P 12903) dates into this period suggesting a more frequent human presence in the eastern Baar and in the small river valleys between the high plateaus of the Swabian Jura. Younger Neolithic land use on the Swabian Jura can be demonstrated by using a charcoal 
sample from the Lindenberg soil profile (P 12896). So far, there have been no indications of a formation of colluvial deposits during this period on the Heuberg. The transition to the Late Neolithic is characterized by a continuous formation of colluvial deposits on the Lindenberg (P 12897) and a new phase of land use on the Heuberg at Königsheim (P 12907). In the Final Neolithic, an intensification of land use on the Heuberg is indicated as the formation of colluvial deposits can be demonstrated in soil profiles at Böttingen (P 12888) and Königsheim (P 12907). In addition, charcoal fragments from a colluvial deposit point to an ongoing land use on the Lindenberg (P 12900, P 12925).

\subsubsection{The Black Forest}

In general, the archaeopedological studies indicate a low human impact in the Black Forest during the Neolithic. Nevertheless, it is striking that the earliest indications of an anthropogenically triggered formation of colluvial deposits in this landscape date to the Younger Neolithic (P 12871). This period is characterized by a significant increase in data for colluviation in the adjacent Baar region suggesting an intensification and expansion of land use. Apparently this was accompanied by a more frequent human presence in the Black Forest. Furthermore, Late Neolithic land use in the Black Forest is indicated by an $\mathrm{AMS}{ }^{14} \mathrm{C}$ age from the spring source of the river Brigach (P 12865). Radiocarbon ages from both the river Brigach (P 12920) and Lehmgrubenhof (GI0315) also point to phases of human presence in the Final Neolithic. The fact that charcoal samples from the spring source area of the river Brigach date into the Late and Final Neolithic may be an indication that humans followed the larger rivers as they entered this landscape. This is also suggested by archaeological finds from the western Baar (Ahlrichs et al., 2016) and by the fragment of a Neolithic blade made of Cretaceous chert found in the colluvial deposits at the spring source of the river Breg (Henkner et al., 2018c).

\section{Discussion of Neolithic settlement dynamics}

\subsection{Early Neolithic (5500-5000 cal BCE)}

During the Early Neolithic, the study area was sparsely populated (Fig. 7). The archaeological record demonstrates human land use in the vicinity of Villingen-Schwenningen at the river Brigach and the spring source of the river Neckar as well as at the Danube in the southern Baar and in the valleys of the Swabian Jura. The pedological data support these archaeological results. Both at the Magdalenenberg (GI0132) and the Fürstenberg (GI0183, GI0184, GI0248, Erl-2027), phases of colluviation were detected dating to the Early Neolithic. In addition, the dating of charcoal sample P 12910 from Königsheim indicates a phase of land use on the Heuberg, a landscape, where no Early Neolithic sites are known so far. The location of Early Neolithic settlements in the immediate vicinity of large rivers in other areas was interpreted in a way that the early farmers followed large rivers when they colonized new territories (Schier, 1990; Bofinger, 2005). Similar locations of settlements were discovered at the river Neckar and in close proximity to the Danube in the Baar region (Ahlrichs, 2017). The artefacts from the settlement at the river Neckar indicate that Neolithic farmers penetrated the Black Forest to extract raw materials. Several grinding stones found in the settlement were made of a type of rock that occurs only in the Black Forest. Furthermore, chunks of haematite were recovered at the site (Schmid, 1992) which was mined in the Black Forest (Ahlrichs, 2015).

\subsection{Middle Neolithic (5000-4400 cal BCE)}

Archaeologically, the Middle Neolithic is characterized by a low site density (Fig. 7). However, the site distribution indicates a continuation of the settlement patterns introduced in the Early Neolithic. In contrast to the Early Neolithic, there is archaeological evidence for hilltop settlements in the southern and eastern Baar. Trends like these have also been observed in the Maindreieck (Schier, 1990) and the Obere Gäue (Bofinger, 2005). In addition, there are archaeological indications of a human presence in the northern Baar and an expansion into the northeastern Baar. However, the artefacts recovered from these four sites cannot be assigned to the Middle Neolithic with absolute certainty as they are also typical for later periods (Ahlrichs, 2017). The pedological data are consistent with the site distribution: radiocarbon and luminescence ages point to a formation of colluvial deposits in the northern Baar (GI0131) and on the Swabian Jura (P 12896, P 12903, P 12910).

\subsection{Younger Neolithic (4400-3500 cal BCE)}

The transition to the Younger Neolithic is characterized by significant reduction in the archaeological data (Fig. 7). This is in strong contrast to other landscapes in southwest Germany where Neolithic farmers expanded their territories (Bofinger, 2005). So far, only one site from the northeastern Baar can be dated directly to this period. Furthermore, there are four sites in the northern Baar and two in the southern Baar dating to the Younger Neolithic. In contrast to the archaeological data, both AMS ${ }^{14} \mathrm{C}$ ages and OSL ages from colluvial deposits indicate land use at the Magdalenenberg (Poz-36954, Erl-20132, GI0131), in the vicinity of Spaichingen (P 12878), at the Fürstenberg (GI0183, GI0184, GI0247, GI0248) and on the Swabian Jura (P 12896). So far, there are neither archaeological nor pedological indications of land use on the Heuberg. However, pollen analysis of a bog profile from Elzhof and a radiocarbon age from Lehmgrubenhof (P 12871) in the southeastern Black Forest point to changes in the vegetation caused by land use during the Younger Neolithic (Henkner et al., 2018a, c). These developments are in line with archaeological and archaeobotanical studies 
(a) All Neolithic sites (5500-2150 cal BCE)

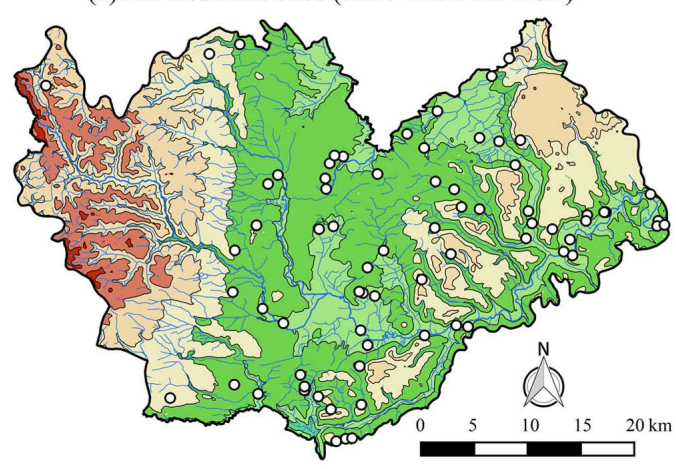

(c) Middle Neolithic (5000-4400 cal BCE)

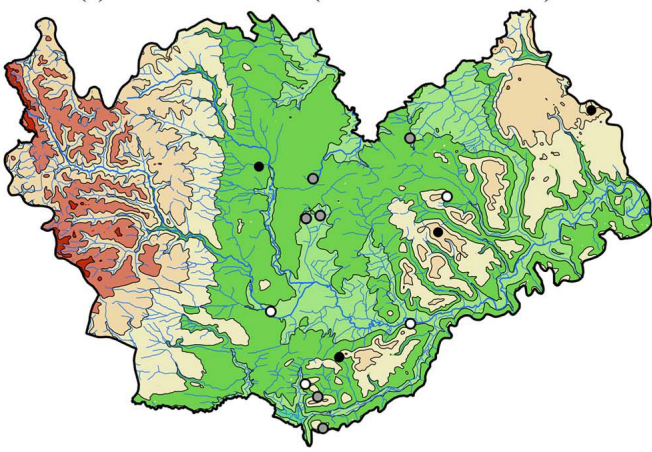

(e) Late Neolithic (3500-2800 cal BCE)

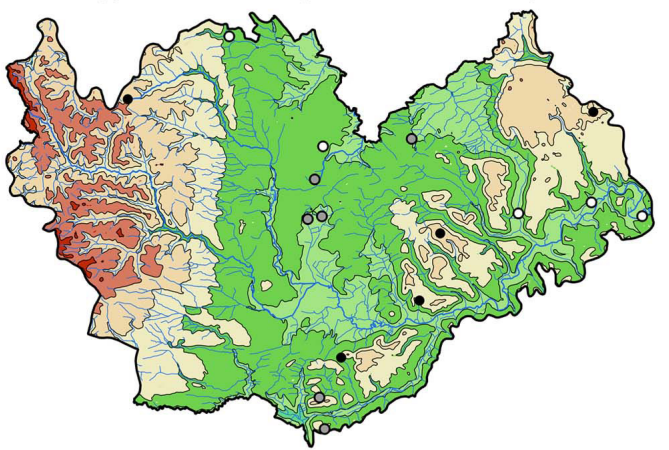

$500-600 \mathrm{~m}$ a.s.l.
$600-700 \mathrm{~m}$ a.s.l.
$700-800 \mathrm{~m}$ a.s.l.

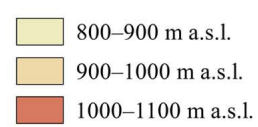

(b) Early Neolithic (5500-5000 cal BCE)

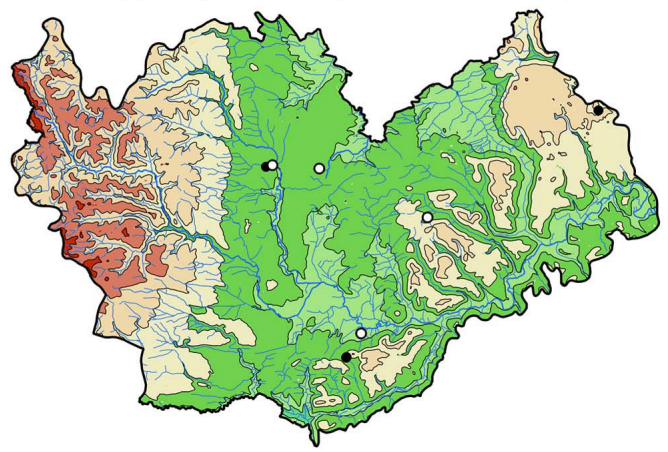

(d) Younger Neolithic (4400-3500 cal BCE)

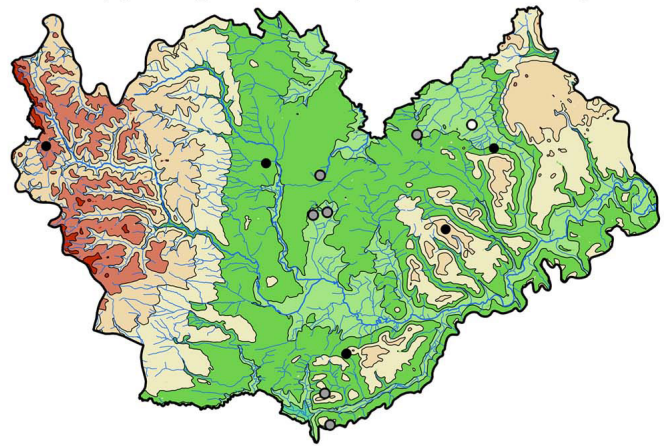

(f) Final Neolithic (2800-2150 cal BCE)

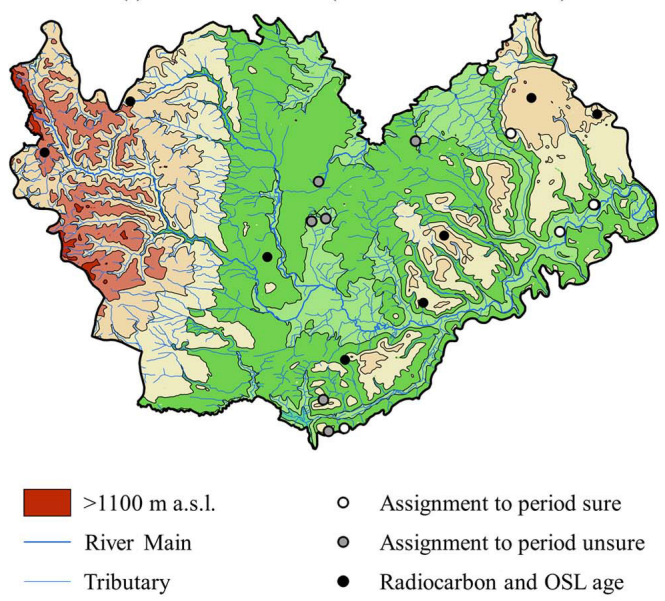

Figure 7. Distribution of all recorded Neolithic sites (a) and reconstruction of Neolithic settlement dynamics during the (b) Early Neolithic, (c) Middle Neolithic, (d) Younger Neolithic, (e) Late Neolithic and (f) Final Neolithic.

from other parts of the Black Forest. Based on archaeological field surveys (Valde-Nowak, 1999; Kienlin and ValdeNowak, 2004; Valde-Nowak and Kienlin, 2002) and pollen records (Frenzel, 1982, 1997; Rösch, 2009), human presence can be demonstrated in the western and northern areas of the Black Forest during the Younger Neolithic. Basically, the archaeological and archaeobotanical results are interpreted as an indication of seasonal land use in the Black Forest, i.e. in the context of a transhumance (Valde-Nowak, 2002). This form of land use leaves few archaeological traces because of its seasonal character and the fact that small mobile groups of shepherds are travelling along with the livestock. In addition, these sites are difficult to find due to the recent reforestation of the Black Forest and sites may have been redeposited or covered by slope deposits (Lais, 1937; Paret, 1961; Pasda, 1998).

Henkner et al. (2017) calculated the summed probability density (SPD) of the radiocarbon and luminescence ages 
for the Baar region. The oldest phase of increased colluvial deposition dates to the Younger Neolithic, where the increase in formations of colluvial deposits took place in a wetter- and colder-climate period. Therefore, higher erosion rates may have been caused by higher amounts of precipitation. Furthermore, the agricultural technology went through major changes during the Younger Neolithic. During the early and Middle Neolithic fields were ploughed manually, whereas farming became more efficient in the Younger Neolithic since new types of ploughs (pulled by cattle) were introduced (Lüning, 2000). This change opens up the possibility of cultivating larger fields, which may have increased local soil erosion processes.

\subsection{Late Neolithic (3500-2800 cal BCE)}

The transition to the Late Neolithic is marked by significant changes in the local settlement pattern (Fig. 7). In contrast to previous periods, several sites were established in the Danube Valley. In the northwestern Baar, a site is situated in a small river valley leading into the Black Forest. This can be taken as an indicator for a temporary human presence in this landscape. Additionally, archaeobotanical analysis of pollen profiles from Elzhof and Moosschachen documented a small human impact during the Late Neolithic in the Black Forest (Henkner et al., 2018c). Furthermore, pedological analysis of colluvial deposits point to human activities on the Heuberg at Königsheim (P 12907) and on the Lindenberg (P 12897, $P$ 12900). Consequently, the Late Neolithic is the first period in which Neolithic societies expanded simultaneously their territories into the eastern Black Forest and western Swabian Jura. The pedological investigations of colluvial deposits at Fürstenberg (Erl-20276, Erl-20277, GI0247) and Geisingen (P 13418, P 14445) point to a human presence in the southern and southeastern Baar during the Late Neolithic for which archaeological evidence still has to be provided.

\subsection{Final Neolithic (2800-2150 cal BCE)}

The general Late Neolithic settlement pattern prevailed during the Final Neolithic (Fig. 7). However, for the first time, there is archaeological evidence for a Neolithic settlement on the Heuberg. The analysis of a colluvial deposit at Böttingen points to human presence near this settlement (P 12888). Furthermore, AMS ${ }^{14} \mathrm{C}$ and OSL dates indicate a phase of colluvial deposition at Grüningen in the western Baar (Erl20137, GI0296).

\section{Conclusion}

We investigated Neolithic settlement dynamics by using an integrated archaeological-archaeopedological approach with a focus on archaeological source criticism and colluvial deposits. Our results lead to the following conclusions.
- Archaeological source criticism indicates that Neolithic settlement dynamics in our study area cannot be described based on the archaeological data alone. The distribution pattern of the sites especially in the low mountain ranges seems to be influenced by various factors: (i) a restricted accessibility of sites due to dense vegetation in forests in the Black Forest and on the Swabian Jura, (ii) a superimposition of sites by colluvial deposits and (iii) weathering effects on the preservation of pottery. These factors contribute to the difficulty of discovering new Neolithic sites by field surveys. Consequently, the Neolithic site frequencies are very low compared to other regions in southwestern Germany.

- A more reliable picture of Neolithic settlement dynamics is achieved by complementing archaeological data and chronological data from colluvial deposits. Thus, we were able to describe settlement dynamics not only between the Baar region and the adjacent low mountain ranges but also within the Baar region for the different chronological levels of the Neolithic.

- Archaeopedological results indicate a continuous land use at the Fürstenberg throughout the Neolithic. This site might have been a particular favourable location because of its proximity to the Danube, which probably served as an important route for communication and trade. This is also suggested by rare imported objects found at the Fürstenberg and in the Danube Valley.

- Archaeological finds point to expeditions into the Black Forest for the extraction of raw material for stone tools and haematite in the Early Neolithic. The formation of colluvial deposits in the eastern Black Forest and western Swabian Jura was triggered most probably by transhumance and small-scale farming in the Late and Final Neolithic.

Data availability. The data used in this paper are stored at Dryad (https://doi.org/10.5061/dryad.rh67h, Henkner, 2018b). Additional information and supplementary data about this project are published (Ahlrichs et al., 2016, 2018a, b; Ahlrichs, 2017; Henkner et al., 2017, 2018a, c).

Author contributions. JJM, JH, PK, TS and TK designed the study, and JJM carried it out. JJM prepared the manuscript with contributions from all co-authors. MF was responsible for OSL dating. KS contributed to the interpretation and discussion of the results of the quantitative analyses.

Competing interests. The authors declare that they have no conflict of interest. 
Special issue statement. This article is part of the special issue "Geoarchaeology and past human-environment interactions". It is not associated with a conference.

Acknowledgements. We acknowledge financial support by the German Research Foundation (DFG) and the SFB 1070 ResourceCultures at the University of Tuebingen. Furthermore, we acknowledge support from the DFG and Leipzig University within the program of Open Access Publishing. We also thank our anonymous reviewers for their helpful comments and suggestions on an earlier draft of this paper.

Financial support. This research has been supported by the German Research Foundation (DFG), the University of Tuebingen (SFB 1070 ResourceCultures), and the Leipzig University (Open Access Publishing).

\section{References}

Ad-hoc-AG Boden: Bodenkundliche Kartieranleitung, KA5, 5th edn., Schweizerbart, Stuttgart, Germany, 2005.

Ahlrichs, J. J.: Ocker im Paläolithikum, Universitätsforschungen zur prähistorischen Archäologie 265, Habelt, Bonn, Germany, 2015.

Ahlrichs, J. J.: Ur- und frühgeschichtliche Siedlungsdynamiken zwischen Gunst- und Ungunsträumen in Südwestdeutschland Eine Fallstudie zur Baar und den angrenzenden Naturräumen des Schwarzwaldes und der Schwäbischen Alb, PhD thesis, Eberhard Karls University Tübingen, Germany, 726 pp., 2017.

Ahlrichs, J., Henkner, J., Teuber, S., Schmidt, K., Scholten, T., Kühn, P., and Knopf, T.: Archaeological and archaeopedological approaches to analyze the development of marginal areas in prehistory: a case study from the western Baar, SW Germany, in: Landscape as impulsion for culture: research, perception \& protection. Landscape in the past \& forgotten landscapes 2, edited by: Kołodziejczyk, P. and Kwiatkowska-Kopka, B., Institute of Archeology Kraków, Institute of Landscape Architecture Kraków, Kraków, Poland, 39-49, available at: https://www.clc. edu.pl/wp-content/uploads/2016/09/VOL_2_CLC2016.pdf (last access: 18 June 2019), 2016.

Ahlrichs, J. J., Henkner, J., Schmidt, K., Scholten, T., Kühn, P., and Knopf, T.: Bronzezeitliche Siedlungsdynamiken zwischen der Baar und angrenzenden Naturräumen, in: Bronzezeitlicher Transport. Akteure, Mittel und Wege. RessourcenKulturen 8, edited by: Neumann, D., Nessel, B., and Bartelheim, M., Tübingen University Press, Tübingen, Germany, 269-303, 2018a.

Ahlrichs, J. J., Henkner, J., Schmidt, K., Scholten, T., Kühn, P., and Knopf, T.: L'utilisation des terres pendant la période néolithique sur la colline du Fürstenberg à la bordure sud du Baar en Allemagne du sud-ouest, in: Habitations et habitat du Néolithique à l'âge du Bronze en France et ses marges. Actes des IIe Rencontres Nord/Sud de Préhistoire récente, Dijon, 19-21 November 2015, edited by: Lemercier, O., Sénépart, I., Besse, M., and Mordant, C., Archives d'Écologie Préhistorique, Toulouse, France, 619-622, 2018b.
Benzing, A. G.: Dr. Rudolf Ströbel, Schriften des Vereins für Geschichte und Naturgeschichte der Baar, 30, 15-19, 1974.

Bofinger, J.: Untersuchungen zur neolithischen Besiedlungsgeschichte des Oberen Gäus, Materialhefte zur Archäologie in Baden-Württemberg 68, Theiss, Stuttgart, Germany, 2005.

Bronk Ramsey, C.: Bayesian analysis of radiocarbon dates, Radiocarbon, 51, 337-360, https://doi.org/10.1017/S0033822200033865, 2009.

Bußmann, J.: Holozäne Sedimentdynamik im Umfeld der Varusschlacht, PhD thesis, University of Osnabrück, Germany, 113 pp., 2014.

Childe, V. G.: Man makes himself, Watts \& Co., London, UK, 1936.

Conrad, O., Bechtel, B., Bock, M., Dietrich, H., Fischer, E., Gerlitz, L., Wehberg, J., Wichmann, V., and Böhner, J.: System for Automated Geoscientific Analyses (SAGA) v. 2.1.4, Geosci. Model Dev., 8, 1991-2007, https://doi.org/10.5194/gmd-8-1991-2015, 2015.

Deecke, W.: Natur, Oberflächengestaltung und Wirtschaftsformen der Baar. Vom Bodensee zum Main - Heimatblätter herausgegeben vom Landesverein badische Heimat 16, Müller, Karlsruhe, Germany, 1921.

Dotterweich, M.: The history of soil erosion and fluvial deposits in small catchments of central Europe: Deciphering the long-term interaction between humans and the environment - A review, Geomorphology, 101, 192-208, https://doi.org/10.1016/j.geomorph.2008.05.023, 2008.

Eberhardt, E., Schad, P., Berner, T., Lehmann, C., Walthert, L., and Pietsch, D.: Ableitungsschlüssel zur Klassifizierung von Böden nach WRB 2007: aus Daten der KA 5-Nomenklatur, Berlin, Germany, available at: http://eprints.dbges.de/id/eprint/980 (last access: 18 June 2019), 2013.

Eggert, M. K. H.: Prähistorische Archäologie: Konzepte und Methoden, UTB 2092, Francke, Tübingen, Germany, 2012.

Eggert, M. K. H. and Samida, S.: Ur- und frühgeschichtliche Archäologie, UTB 3254, Francke, Tübingen, Germany, 2013.

European Environment Agency: CLC2006 technical guidelines, EEA Technical report 17, Office for Official Publications of the European Communities, Luxembourg, https://doi.org/10.2800/12134, 2007.

FAO: Guidelines for soil description, 4th edn., Food and Agriculture Organization of the United Nations, Rome, Italy, 2006.

Fischer, E.: Beiträge zur Kulturgeographie der Baar. Badische Geographische Abhandlungen 16, Waibel, Freiburg im Breisgau, Germany, 1936.

Frenzel, B.: Über eine vormittelalterliche Besiedlung in einigen Teilen des nördlichen Schwarzwaldes, in: Geschichte und Naturwissenschaft in Hohenheim Beiträge zur Natur-, Agrar-, Wirtschafts- und Sozialgeschichte Südwestdeutschlands: Festschrift für Günther Franz zum 80. Geburtstag, edited by: Winkel, H., Thorbecke, Sigmaringen, Germany, 239-263, 1982.

Frenzel, B.: Vegetationsgeschichtliche und paläoökologische Probleme des Schwarzwaldes, in: Erstes NordschwarzwaldSymposium: Siedlungsgeschichte und Waldnutzungsformen, Baiersbronn 1994. Veröffentlichungen des Alemannischen Instituts 64, edited by: Lohrenz, S. and Matzke, M., Heimat- und Museumsverein für Stadt und Kreis Freudenstadt, Freudenstadt, Germany, 11-40, 1997. 
Fuchs, M. and Lang, A.: Luminescence dating of hillslope deposits - a review, Geomorphology, 109, 17-26, https://doi.org/10.1016/j.geomorph.2008.08.025, 2009.

Fuchs, M., Will, M., Kunert, E., Kreutzer, S., Fischer, M., and Reverman, R.: The temporal and spatial quantification of Holocene sediment dynamics in a meso-scale catchment in northern Bavaria/Germany, Holocene, 21, 1093-1104, https://doi.org/10.1177/0959683611400459, 2011.

Gebhard, K.: Die vorgeschichtliche Besiedlung des Kreises GroßGerau. Materialien zur Vor- und Frühgeschichte von Hessen 25, Selbstverlag des Landesamtes für Denkmalpflege Hessen, Wiesbaden, Germany, 2007.

Geilmann, W. and Spang, A.: Eine Beobachtung zur Schnelligkeit der Zerstörung keramischer Scherben auf der Erdoberfläche. Die Kunde, Neue Folge, 9, 93-94, 1958.

Gerhard, S.: Beiträge zur archäologischen Quellenkritik an Beispielen aus dem Neolithikum und der Frühbronzezeit Südbayerns, Arbeiten zur Archäologie Süddeutschlands 18, Faustus, Büchenbach, Germany, 2006.

Gerlach, R.: Wie dynamisch sind die geogenen Grundlagen einer archäologischen Prognose? Die Veränderungen von Relief, Boden und Wasser seit dem Neolithikum, in: Archäoprognose Brandenburg I. Symposium Landschaftsarchäologie und geographische Informationssysteme. Forschungen zur Archäologie im Land Brandenburg 8, edited by: Kunow, J. and Müller, J., Brandenburgisches Landesamt für Denkmalpflege und Archäologisches Landesmuseum, Wünsdorf, Germany, 89-96, 2003.

Gerlach, R.: Holozän: Die Umgestaltung der Landschaft durch den Menschen seit dem Neolithikum, Jahrbuch des Rheinischen Vereins für Denkmalpflege und Landschaftsschutz, 2005, 87-98, 2006.

Gradmann, R.: Süddeutschland II. Die einzelnen Landschaften, Gentner, Darmstadt, Germany, 1931.

Gradmann, R.: Altbesiedeltes und jungbesiedeltes Land, Studium Generale, 1-3, 163-177, 1948.

Hall, A.: Dr. Paul Revellio. Schriften des Vereins für Geschichte und Naturgeschichte der Baar, 27, V-IX, 1968.

Haug, F. and Sixt, G.: Die römischen Inschriften und Bildwerke Württembergs, second edn., Kohlhammer, Stuttgart, Germany, 1914.

Henkner, J., Ahlrichs, J. J., Downey, S., Fuchs, M., James, B. R., Knopf, T., Scholten, T., Teuber, S., and Kühn, P.: Archaeopedology and chronostratigraphy of colluvial deposits as a proxy for regional land use history (Baar, southwest Germany), Catena, 155, 93-103, https://doi.org/10.1016/j.catena.2017.03.005, 2017.

Henkner, J., Ahlrichs, J., Downey, S., Fuchs, M., James, B., Junge, A., Knopf, T., Scholten, T., and Kühn, P.: Archaeopedological analysis of colluvial deposits in favourable and unfavourable areas: reconstruction of land use dynamics in SW Germany, Roy. Soc. Open Sci., 5, 171624, https://doi.org/10.1098/rsos.171624, 2018a.

Henkner, J., Ahlrichs, J., Downey, S., Fuchs, M., James, B., Junge, A., Knopf, T., Scholten, T., and Kühn, P.: Archaeopedological analysis of colluvial deposits in favourable and unfavourable areas: reconstruction of land use dynamics in SW Germany, Dryad Digital Repository, https://doi.org/10.5061/dryad.rh67hb, 2018 b.

Henkner, J., Ahlrichs, J., Fischer, E., Fuchs, M., Knopf, T., Rösch, M., Scholten, T., and Kühn, P.: Land use dynam- ics derived from colluvial deposits and bogs in the Black Forest, Germany, J. Plant Nutr. Soil Sci., 181, 240-260, https://doi.org/10.1002/jpln.201700249, 2018c.

Ihm, P., Lüning, J., and Zimmermann, A.: Statistik in der Archaeologie: Probleme der Anwendung, allgemeine Methoden, Seriation und Klassifikation, Archaeo-Physika 9, Habelt, Bonn, Germany, 1978.

Itten, M.: Die Horgener Kultur. Monographien zur Urund Frühgeschichte der Schweiz 17, Die Schweizerische Gesellschaft für Ur- und Frühgeschichte, Basel, Switzerland, 1970.

IUSS Working Group WRB: World reference base for soil resources 2014, update 2015. International soil classification system for naming soils and creating legends for soil maps, World soil resources reports 106, Rome, Italy, 2015.

Jarvis, A., Reuter, H. I., Nelson, A., and Guevara, E.: Holefilled SRTM for the globe Version 4, CGIAR-CSI SRTM 90m Database, available at: http://srtm.csi.cgiar.org (last access: 18 June 2019), 2008.

Kadereit, A., Kühn, P., and Wagner, G. A.: Holocene relief and soil changes in loess-covered areas of south-western Germany: The pedosedimentary archives of BrettenBauerbach (Kraichgau), Quaternary Int., 222, 96-119, https://doi.org/10.1016/j.quaint.2009.06.025, 2010.

Kienlin, T. L. and Valde-Nowak, P.: Neolithic Transhumance in the Black Forest Mountains, SW Germany, J. Field Archaeol. 29, 29-44, https://doi.org/10.1179/jfa.2004.29.1-2.29, 2004.

Knoch, K.: Klima-Atlas von Baden-Württemberg, Deutscher Wetterdienst, Bad Kissingen, Germany, 1953.

Kösel, M. and Rilling, K.: Die Böden der Baar - ein Beitrag zur regionalen Bodenkunde Südwestdeutschlands, Schriften des Vereins für Geschichte und Naturgeschichte der Baar, 45, 99-128, 2002.

Kreutzer, S., Dietze, M., Burow, C., Fuchs, M. C., Schmidt, C., Fischer, M., Firedrich, J., Mercier, N., Smedley, R. K., Durcan, J., and King, G.: Comprehensive Luminescence Dating Data Analysis (R package), available at: https://cran.r-project.org/web/ packages/Luminescence/index.html (last access: 18 June 2019), 2016.

Krippner, F.: Siedlungskundliches aus dem Ries. Eine erste Zusammenfassung der systematischen Begehungen, Bayerische Vorgeschichtsblätter, 60, 63-80, 1995.

Kühn, P., Lehndorff, E., and Fuchs, M.: Lateglacial to Holocene pedogenesis and formation of colluvial deposits in a loess landscape of Central Europe (Wetterau, Germany), Catena, 154, 118 135, https://doi.org/10.1016/j.catena.2017.02.015, 2017.

Lais, R.: Die Steinzeit im Schwarzwald, Badische Fundberichte, 13, 29-66, 1937.

Lazar, S.: Bodenzustandsbericht Baar. Bodenschutz 19, Landesanstalt für Umweltschutz Baden-Württemberg, Karlsruhe, Germany, 2005.

Lazar, S. and Rilling, K.: Die Böden der Baar, in: Faszination Baar, edited by: Siegmund, A., Mory's Hofbuchhandlung, Donaueschingen, Germany, 37-56, 2006.

Leopold, M. and Völkel, J.: Colluvium: Definition, differentiation, and possible suitability for reconstructing Holocene climate data, Quaternary Int., 162-163, 133-140, https://doi.org/10.1016/j.quaint.2006.10.030, 2007. 
Lomax, J., Kreutzer, S., and Fuchs, M.: Performance tests using the Lexsyg luminescence reader, Geochronometria, 41, 327-333, https://doi.org/10.2478/s13386-013-0174-x, 2014.

Lüning, J.: Steinzeitliche Bauern in Deutschland. Die Landwirtschaft im Neolithikum, Universitätsforschungen zur prähistorischen Archäologie 58, Habelt, Bonn, Germany, 2000.

Murray, A. S. and Wintle, A. G.: Luminescence dating of quartz using an improved singlealiquot regenerative-dose protocol, Radiat. Meas., 32, 57-73, https://doi.org/10.1016/S13504487(99)00253-X, 2000.

Niller, H.-P.: Niller, Prähistorische Landschaften im Lößgebiet bei Regensburg, Kolluvien, Auenlehme und Böden als Archive der Paläoumwelt, Regensburger Geographische Schriften 31, Institut für Geographie, Regensburg, Germany, 1998.

Obst, R.: Die Besiedlungsgeschichte am nordwestlichen Maindreieck vom Neolithikum bis zum Ende des Mittelalters, Würzburger Arbeiten zur prähistorischen Archäologie 4, Leidorf, Rahden, Germany, 2012.

Pankau, C.: Die Besiedlungsgeschichte des Brenz-Kocher-Tals (östliche Schwäbische Alb) vom Neolithikum bis zur Latènezeit, Universitätsforschungen zur prähistorischen Archäologie 142, Habelt, Bonn, Germany, 2007.

Pape, W.: Bemerkungen zur relativen Chronologie des Endneolithikums am Beispiels Südwestdeutschlands und der Schweiz, Tübinger Monographien zur Urgeschichte 3, Archaeologica Venatoria, Tübingen, Germany, 1978.

Paret, O.: Württemberg in vor- und frühgeschichtlicher Zeit. Veröffentlichungen der Kommission für Geschichtliche Landeskunde in Baden Württemberg, Reihe B, Band 17, Kohlhammer, Stuttgart, Germany, 1961.

Pasda, C.: Altensteig und Ettlingen - Mesolithische Fundstellen am Rand des Nordschwarzwalds, Fundberichte aus BadenWürttemberg, 19, 99-174, 1994.

Pasda, C.: Zur Erhaltung steinzeitlicher Fundstellen in Flußtälern der Mittelgebirge - Ein Beispiel aus dem Nordschwarzwald, in: Aktuelle Forschungen zum Mesolithikum, in: Urgeschichtliche Materialhefte 12, edited by: Conard, N. J. and Kind, C.-J., MoVince, Tübingen, Germany, 223-228, 1998.

Pietsch, D. and Kühn, P.: Buried soils in the context of geoarchaeological research - two examples from Germany and Ethiopia, Archaeol. Anthropol. Sci., 9, 1571-1583, https://doi.org/10.1007/s12520-014-0180-9, 2017.

Reich, L.: Die badische Landschaft Baar, Badenia oder das badische Land und Volk, 1, 431-461, 1859.

Reichelt, G.: Die Landschaft und ihr natürliches Gefüge, in: Der Schwarzwald-Baar-Kreis, edited by: Gutknecht, R., Theiss, Stuttgart, Germany, 37-55, 1977.

Reimann, T., Román-Sánchez, A., Vanwalleghem, T., and Wallinga, J.: Getting a grip on soil reworking - Singlegrain feldspar luminescence as a novel tool to quantify soil reworking rates, Quat. Geochronol., 42, 1-14, https://doi.org/10.1016/j.quageo.2017.07.002, 2017.

Reimer, P., Bard, E., Bayliss, A., and Beck, J. W.: IntCal13 and Marine13 radiocarbon age calibration curves 0-50000 years cal BP, Radiocarbon, 55, 1869-1887, https://doi.org/10.2458/azu_js_rc.55.16947, 2013.

Revellio, P.: Die Baar in vor- und frühgeschichtlicher Zeit. Neue und alte Funde, Schriften des Vereins für Geschichte und Naturgeschichte der Baar, 14, 35-53, 1924.
Revellio, P.: Aus der Ur- und Frühgeschichte der Baar, Link, Schwenningen a. N., Germany, 1932.

Revellio, P.: Die Baar in vor- und frühgeschichtlicher Zeit, in: Die Baar: Donaueschingen - Villingen, Badische Heimat 25, edited by: Busse, H. E., Haus Badische Heimat, Freiburg im Breisgau, Germany, 58-71, 1938.

Rösch, M.: Botanical evidence for prehistoric and medieval land use in the Black Forest, in: Medieval Rural Settlement in Marginal Landscapes, Ruralia VII, 8-14 September 2007, Cardiff, Wales, UK, edited by: Klápšte, J., Brepols, Turnhout, UK, 335-343, 2009.

Saile, T.: Holozäner Bodenabtrag im Bereich einer bandkeramischen Siedlung am Rande des Reinheimer Beckens bei Wembach, Archäol. Korresponden., 23, 187-196, 1993.

Saile, T.: Untersuchungen zur ur- und frühgeschichtlichen Besiedlung der nördlichen Wetterau. Materialien zur Vor- und Frühgeschichte von Hessen 21, Selbstverlag des Landesamtes für Denkmalpflege Hessen, Wiesbaden, Germany, 1998.

Saile, T.: Relief Intensity and the Formation of the Archaeological Record, in: Classification, Automation, and New Media. Studies in Classification, Data Analysis, and Knowledge Organization, edited by: Gaul, W. and Ritter, G., Springer, Berlin, Germany, 479-489, https://doi.org/10.1007/978-3-642-55991-4_52, 2002.

Schefzik, M.: Die bronze- und eisenzeitliche Besiedlungsgeschichte der Münchner Ebene: eine Untersuchung zu Gebäude- und Siedlungsformen im süddeutschen Raum, Internationale Archäologie 68, Leidorf, Rahden/Westfalen, Germany, 2001.

Schier, W.: Zur vorrömischen Besiedlung des Donautales südöstlich von Regensburg, Bayerische Vorgeschichtsblätter, 50, 9-80, 1985.

Schier, W.: Die vorgeschichtliche Besiedlung im südlichen Maindreieck. Materialhefte zur bayerischen Vorgeschichte 60, Lassleben, Kallmünz/Opf, Germany, 1990.

Schiffer, M. B.: Formation Processes of the Archaeological Record, University of New Mexico Press, Albuquerque, USA, 1987.

Schmid, B.: Die urgeschichtlichen Funde und Fundstellen der Baar: Eine Auswertung des Bestandes. Band 1: Text und Tafeln, Schäuble, Rheinfelden, Germany, 1991.

Schmid, B.: Die urgeschichtlichen Funde und Fundstellen der Baar: Eine Auswertung des Bestandes. Band 2: Katalog, Schäuble, Rheinfelden, Germany, 1992.

Schmotz, K.: Die vorgeschichtliche Besiedlung im Isarmündungsgebiet, Materialhefte zur bayerischen Vorgeschichte 58, Lassleben, Kallmünz/Opf, Germany, 1989.

Schmotz, K.: Kritische Anmerkungen zur Kenntnis vorgeschichtlicher Siedlungsabläufe am Beispiel des Isarmündungsgebietes, in: Archäologische Arbeitsgemeinschaft Ostbayern/West- und Südböhmen, 6. Treffen 12. bis 15. Juni 1996 in Hluboká nad Vltavou, Resümees der Vorträge, edited by: Michálek, J., Schmotz, K., and Zápotocká, M., Leidorf, Espelkamp, Germany, 54-62, 1997.

Schmotz, K.: Zur Besiedlung im Umfeld der Isarmündung während des 4. und 3. Jahrtausends v. Chr.: Quellenlage und Grenzen der Interpretation, in: Mensch und Umwelt während des Neolithikums und der Frühbronzezeit in Mitteleuropa, Internationale Archäologie: Arbeitsgemeinschaft, Symposium, Tagung, Kongress 2, edited by: Lippert, A., Leidorf, Rahden/Westfalen, Germany, 61-72, 2001. 
Schreg, R.: Uncultivated landscapes or wilderness? Early medieval land use in low mountain ranges and flood plains of Southern Germany, European Journal of Post-Classical Archaeologies, 4, 69-98, 2014.

Schröder, K. H.: Naturräumliche Grundlagen der Landesgeschichte, in: Handbuch der baden-württembergischen Geschichte. Band 1: Von der Urzeit bis zum Ende der Staufer, edited by: Schaab, M. and Schwarzmaier, H., Klett-Cotta, Stuttgart, Germany, 1-27, 2001.

Seidel, U.: Fürstenberg (Schwarzwald-Baar-Kreis), Fundberichte aus Baden-Württemberg, 35, 895-906, 2015.

Semmel, A.: Bodenkundliche Hinweise auf Ackernutzung und intensive Bodenerosion um 8000 B.P. im Rhein-Main-Gebiet, Archäol. Korresponden., 25, 157-163, 1995.

Shennan, S.: Quantifying archaeology, Edinburgh University Press, Edinburgh, UK, 1988.

Siegmund, A.: Das Klima der Baar: regionalklimatische Studien einer Hochmulde zwischen Schwarzwald und Schwäbischer Alb, PhD thesis, University of Mannheim, Germany, 1999.

Siegmund, A.: Der Klimacharakter der Baar - ein regionales Querprofil, in: Faszination Baar, edited by: Siegmund, A., Mory's Hofbuchhandlung, Donaueschingen, Germany, 57-74, 2006.

Sommer, U.: Zur Entstehung archäologischer Fundvergesellschaftungen: Versuch einer archäologischen Taphonomie, Universitätsforschungen zur prähistorischen Archäologie 6, Habelt, Bonn, Germany, 1991.

Spindler, K.: Aus der Geschichte: Vor- und Frühgeschichte, in: Der Schwarzwald-Baar-Kreis, edited by: Gutknecht, R., Theiss, Stuttgart, Germany, 56-84, 1977.

Starkel, L.: Man as Cause of Sedimentological Changes in the Holocene, Striae, 26, 5-12, 1987.

Stoll, H.: Die früheste Besiedlung der deutschen Mittelgebirge, ein Vergleich: Schwarzwald - Sudeten, Schlesische Blätter, Ausgabe B. Mitteilungen des Landesamtes für Geschichte und des Schlesischen Altertumsvereins, 3, 181-185, 1941.

Stoll, H.: Urgeschichte des Oberen Neckargebietes und der Baar, Habilitation thesis, University of Freiburg, Freiburg im Breisgau, Germany, 1942.

Tanha, A.: Das Schichtstufenrelief der Baar: Morphodynamik und Morphogenese, $\mathrm{PhD}$ thesis, Eberhard Karls University Tübingen, Germany, 244 pp., 1986.

Taylor, R. E. and Bar-Yosef, O.: Radiocarbon Dating: An Archaeological Perspective, Left Coast Press, Walnut Creek, USA, 2014.

Teuber, S., Ahlrichs, J. J., Henkner, J., Knopf, T., Kühn, P., and Scholten, T.: Soil cultures - the adaptive cycle of agrarian soil use in Central Europe: an interdisciplinary study using soil scientific and archaeological research, Ecol. Soc., 22, 13, https://doi.org/10.5751/ES-09729-220413, 2017.
Valde-Nowak, P.: Neolithic penetration of European Mid Mountains, Archaeologia Polona, 37, 3-12, 1999.

Valde-Nowak, P.: Siedlungsarchäologische Untersuchungen zur neolithischen Nutzung der mitteleuropäischen Gebirgslandschaften, Internationale Archäologie 69, Rahden/Westf., 2002.

Valde-Nowak, P. and Kienlin, T. L.: Neolithische Transhumanz in den Mittelgebirgen: Ein Survey im westlichen Schwarzwald, Praehist. Z., 77, 29-75, https://doi.org/10.1515/prhz.2002.77.1.29, 2002.

Voigt, R.: Kolluvien als Archive für anthropogen ausgelöste Landschaftsveränderungen an Beispielen aus der westlichen Bodenseeregion, Materialhefte zur Archäologie in BadenWürttemberg 99, Theiss, Stuttgart, Germany, 2014.

Wagner, E.: Fundstätten und Funde aus vorgeschichtlicher, römischer und alamannisch-fränkischer Zeit im Grossherzogtum Baden. Band 1: Das badische Oberland: Kreise Konstanz, Villingen, Waldshut, Lörrach, Freiburg, Offenburg, Mohr, Tübingen, Germany, 1908.

Wagner, H.: Von der Steinzeit zur Stadt: Neue Forschungen zur Besiedlungsgeschichte des Fürstenbergs, Schriften des Vereins für Geschichte und Naturgeschichte der Baar, 57, 33-62, 2014.

Wahle, E.: Beiwort zu den Karten III, 1-2. Historischer Atlas von Baden-Württemberg, Band III: Vor- und Frühgeschichte, edited by: Kommission für Geschichtliche Landeskunde in Baden-Württemberg and Landesvermessungsamt Baden-Württemberg, Landesvermessungsamt Baden-Württemberg, Stuttgart, Germany, available at: https://www.leo-bw.de/detail-gis/-/Detail/details/DOKUMENT/ kgl_atlas/HABW_03_01/Das+b\%C3\%A4uerliche+Neolithikum (last access: 18 June 2019), 1973.

Wilbertz, O. M.: Die Urnenfelderkultur in Unterfranken, Materialhefte zur Bayerischen Vorgeschichte 49, Lassleben, Kallmünz/Opf, Germany, 1982.

Wunderlich, J.: Prähistorische und historische Bodenerosion im Amöneburger Becken - Abgeleitet aus einer Sequenz datierter Kolluvien, Berichte der Kommission für Archäologische Landesforschung in Hessen, 5, 9-15, 2000.

Yokoyama, R., Shirasawa, M., and Pike, R. J.: Visualizing Topography by Openness: A New Application of Image Processing to Digital Elevation Models, Photogramm. En. Rem. S., 68, 257 265, 2002. 